\title{
Herbivore Dynamics and Range Contraction in Kajiado County Kenya: Climate and Land Use Changes, Population Pressures, Governance, Policy and Human-wildlife Conflicts
}

\author{
Joseph O. Ogutu ${ }^{1,2, *}$, Hans-Peter Piepho ${ }^{1}$, Mohammed Y. Said ${ }^{2}$ and Shem C. Kifugo ${ }^{2}$ \\ ${ }^{I}$ University of Hohenheim, Institute for Crop Science-340, 70599 Stuttgart, Germany \\ ${ }^{2}$ International Livestock Research Institute, P.O. Box 30709-00100, Nairobi, Kenya
}

\begin{abstract}
Wildlife populations are declining severely in many protected areas and unprotected pastoral areas of Africa. Rapid large-scale land use changes, poaching, climate change, rising population pressures, governance, policy, economic and socio-cultural transformations and competition with livestock all contribute to the declines in abundance. Here we analyze the population dynamics of 15 wildlife and four livestock species monitored using aerial surveys from 1977 to 2011 within Kajiado County of Kenya, with a rapidly expanding human population, settlements, cultivation and other developments. The abundance of the 14 most common wildlife species declined by $67 \%$ on average $(2 \% / \mathrm{yr})$ between 1977 and 2011 in both Eastern (Amboseli Ecosystem) and Western Kajiado. The species that declined the most were buffalo, impala, wildebeest, waterbuck, oryx, hartebeest, Thomson's gazelle and gerenuk in Eastern Kajiado (70\% to $88 \%$ ) and oryx, hartebeest, impala, buffalo, waterbuck, giraffe, eland and gerenuk in Western Kajiado (77\% to 99\%). Only elephant $(115 \%)$ and ostrich $(216 \%)$ numbers increased contemporaneously in Eastern and Western Kajiado, respectively. Cattle and donkey numbers also decreased on average by $78 \%$ in Eastern Kajiado and by $37 \%$ in Western Kajiado. Sheep and goats decreased the least in Eastern (28\%) but increased in Western (96\%) Kajiadio. Livestock dominated $(70-80 \%)$ the total large herbivore biomass throughout the 1977-2011 monitoring period. The distribution of wildlife contracted dramatically during 1977-2011, most especially for wildebeest, giraffe and impala. Only zebra and ostrich distributions expanded in the county. However, livestock distribution expanded to densely cover most of the county. Our findings point to recurrent droughts, intensifying human population pressures, land use changes and other anthropogenic impacts, decades of ineffective or failed government policies, legislations, law enforcement, management institutions and strategies as the salient causes of the declines and range compressions. We recommend several urgent measures to rehabilitate the depleted wildlife populations and habitat richness, restore their ecological resilience to droughts and secure pastoral livelihoods.
\end{abstract}

Keywords: Climate change, governance, human wildlife-conflicts, land use change, livestock, policy, population dynamics, pastoralism, rainfall influences, wildlife.

\section{INTRODUCTION}

Wildlife populations are in decline in large parts of their historic geographic ranges worldwide. Studies of animal population dynamics are therefore crucial in helping identify underlying causes, detect patterns of conservation concern before they become too advanced, assess the effectiveness of management interventions and anticipate likely future population trajectories. In particular, wildlife populations are declining markedly throughout large parts of Africa (Ogutu \& Owen-Smith 2003, Brashares et al. 2004, Caro \& Scholte 2007, Fischer \& Linsenmair 2007, Scholte et al. 2007, van Vliet et al. 2007, Craig et al. 2010, Scholte 2011). In East Africa, severe declines have been documented for vast areas of Tanzania (Stoner et al. 2006, 2007), including the Katavi-

*Address correspondence to this author at the Institute for Crop Science340, 70599 Stuttgart, Germany; Tel: +49-711-459-23022;

Fax: +49-711-459-24345; E-mail: jogutu2007@gmail.com
Rukwa (Caro 2008) and the Tarangire-Simanjiro (Msoffe et al. 2011) ecosystems. In Kenya, catastrophic wildlife declines are occurring within major parks, reserves and pastoral lands (Norton-Griffiths 1996, 2000, 2007, Ottichilo et al. 2000, 2001, Homewood et al. 2001, Serneels \& Lambin 2001, Ogutu et al. 2009, 2011, 2012, 2013, Western et al. 2009, Bhola et al. 2012a, b). The declines threaten wildlife in parks no less than outside and in turn the lucrative tourist and hunting industries across Africa (Sindiga 1999, Jones 2001).

The wildlife declines in Africa are attributed primarily to anthropogenic causes, but often without compelling quantitative evidence. These include changing (1) land use/cover, (2) demographic processes, (3) cultural traditions, practices and attitudes of local people towards wildlife and their habitats, (4) economic factors, (5) governmental institutions, (6) policies and legislations governing natural resources and environmental protection and management responsibilities, (7) ecological conditions and (8) their 
interactions (King 2011). Most of the suggested drivers are not root causes but proximate factors that drive human livelihood activities, choices and decision-making in response to prevailing opportunities and circumstances (Ottichilo et al. 2000, 2001, Homewood et al. 2001, Ogutu et al. 2009, Western et al. 2009, King 2011). The manifold, dynamic, shifting and interactive drivers complicate identification and characterization of specific drivers and hence development of management interventions able to counteract the population declines and range constrictions for particular localities (Norton-Griffiths 1996, 2000, Ogutu et al. 2009; Western et al. 2009).

Kajiado County $\left(21901 \mathrm{~km}^{2}, 36^{\circ} 5^{\prime} \mathrm{E}-37^{\circ} 55^{\prime} \mathrm{E}, 10^{\circ} 10^{\prime}\right.$ $\mathrm{S}-30^{\circ} 10^{\prime} \mathrm{S}$ ), located in the southern section of the Eastern Great Rift Valley in Kenya, encompasses the Athi-Kaputiei ecosystem $\left(2,200 \mathrm{~km}^{2}\right)$ within its northern half, the Greater Amboseli Ecosystem $\left(7730.32 \mathrm{~km}^{2}\right)$ to the east and the Western Kajiado ecosystem $\left(11388.54 \mathrm{~km}^{2}\right)$ to the west (Fig. 1). The Nairobi National Park $\left(117 \mathrm{~km}^{2}\right)$, established in 1946 and forming the northernmost section of the AthiKaputiei ecosystem, neighbours the Nairobi Metropolis, with a population of over 3 million people. The county ranks among Kenya's leading tourist destinations owing to high wildlife abundance and diversity within its national parks, reserves, private conservancies and pastoral ranches (Okello \& Kiringe 2004; Kioko \& Okello 2010). But this rich wildlife heritage is now gravely threatened by intensifying population pressures and land use/cover changes compounded by climate change, like in most other pastoral counties of Kenya. The land use changes include sedentarization of formerly semi-nomadic pastoralists, expansion of settlements, cultivation and construction of development infrastructure. The landscape changes lead to human encroachment on wildlife habitats, escalating range degradation, fragmentation and loss and human-wildlife conflicts (Western \& Nightingale 2003, Western et al. 2010). Additional threats include escalating bushmeat hunting and commerce due to easy availability of firearms for poachers (Barnett 1997, 2000, Wato et al. 2006), ineffective law enforcement and less rigorous prosecution of poachers by the Kenyan legal system (Kahumbu et al. 2014), unregulated fencing (Okello \& Kiringe 2004, Ogutu et al. 2013), competition between wildlife and livestock and heavy reliance on natural resources due to widespread poverty (Parker \& Smith 2001, Grieves-Cook 2011, Heath 2011). Corruption and mismanagement (Mburu 2004, Gichohi 2011, Kaka 2011), recurrent severe droughts and habitat desiccation due to rising temperatures (Altmann et al. 2002; Ogutu et al. 2008) further aggravate these threats.

\section{POPULATION PRESSURE}

Kenya Government censuses have documented a 10-fold increase in human population in Kajiado County from 85,903 in 1969 through 406,054 in 1999 to 687,312 by 2009. The annual population growth rate in the County of over $4 \%$ exceeds the national average of about 3.1\% (Ntiati 2002, Campbell et al. 2003). The demographic changes are linked to expansion of urban centres, intensifying land use and expanding subsistence and commercial agriculture, supported by Mt. Kilimanjaro's runoff, settlements, development infrastructure, poaching and human-wildlife conflicts
(Mworia et al. 2008, Okello et al. 2009, Okello \& Kioko 2011).

\section{LAND USE/COVER CHANGES}

Privatization of land tenure, subdivision, and commercialization of communal rangelands to secure legal title to land have been followed by disaggregation of settlements in Kajiado. The formerly semi-nomadic Maasai pastoralists move to settle and manage livestock on their individual parcels, lease or sell land to immigrant cultivators with no history of living with wildlife (Kimani \& Pickard 1998, Campbell et al. 2000, Western et al. 2009, Groom \& Western 2013). Sedentarization causes intensification of land use as livestock regularly graze and trample on vegetation around settlements. This increases erosion and homogenizes the landscape, reducing wildlife abundance and diversity, forage quantity and quality (Worden et al. 2003, Boone \& Hobbs 2004). The high potential wetter margin areas are selectively excised and converted to other uses (Ntiati 2002). Wildlife revenue is often invested in funding land subdivision, purchasing more livestock and in cultivation, undermining conservation goals (Meguro \& Inoue 2011). Notably, land subdivision has made negotiation of access to communal grazing lands extremely difficult for pastoral livestock keepers (Okello \& Kiringe 2004, Western \& Nightingale 2003, Seno \& Shaw 2002).

The changes in land tenure, the consequent land subdivision, expansion of settlements, cultivation, fences and development of infrastructure in Kajiado have adversely affected wildlife and livestock populations alike. Settlements in the Amboseli ecosystem increased from under 1000 in 1973 to over 10000 by 2000 and at a faster rate in areas with higher settlement or arable potential, which are also the best places for wildlife (Western \& Dunne 1979; Western \& Nightingale 2003). Cultivated land in Eastern Kajiado increased from under $400 \mathrm{~km}^{2}$ in 1989 to over $900 \mathrm{~km}^{2}$ by 1994 (Kioko \& Okello 2010). Cultivation now covers large swathes of grasslands and wetlands traditionally used by livestock and wildlife as dry-season concentration and wet season dispersal areas, especially on the slopes of Mt. Kilimnjaro where over $200 \mathrm{~km}^{2}$ is under rain-fed agriculture. Irrigated agriculture also occupies large parts of Kimana and Kuku Group Ranches that link Tsavo West, Chyullu Hills and Amboseli National Parks (Kioko et al. 2006b).

All the four protected areas in Kajiado are centered on dry season wildlife refuges and are too small to support their current wildlife populations without seasonal access to the surrounding pastoral areas, as with many African parks (Fynn \& Bonyongo 2011). A large percentage of wildlife in Kajiado, as elsewhere in Kenya (65-75\%), live permanently on, or seasonally use, pastoral lands outside the protected areas (Wishitemi \& Okello 2003, Okello et al. 2005, Western et al. 2009; Okello \& Kioko 2010, Okello \& Kioko 2011). At least $80 \%$ of the large mammals from the Amboseli National Park disperse to the neighbouring Maasai Group ranches in the wet season. The grasslands and wetlands in the ranches adjoining the small protected areas are therefore critical to successful wildlife conservation and pastoralism in Kajiado. 
The expansion of agriculture, settlements, fences, infrastructure and demand for fuel wood and construction materials in the dispersal areas with high arable potential in the group ranches increasingly contract wildlife dispersal ranges, insularizing parks and threatening wildlife conservation and pastoralism in Kajiado (Okello \& Kioko 2010). The consequent fragmentation and degradation of natural habitats lower the numbers of large mammals that they can support, constrict wildlife distribution and accelerate local extirpation of wildlife populations. This is most evident in the highly settled regions of the County (e.g. Loitokitok, Ngong and Kitengela). Together with diversion of scarce water resources for domestic, urban, industrial and agricultural uses, these changes compress wildlife and livestock into ever smaller areas. Wildlife dispersal and migratory corridors are being blocked or lost and their seasonal dispersal movements and access to water, foraging and breeding grounds obstructed (Kioko \& Okello 2010, Okello \& D'Amour, 2008, Fynn \& Bonyongo 2010). This forces wildlife to reside longer near a few accessible water sources (Western 1982, 1994), accentuating habitat degradation and the risk of disease transmission (Western \& Maitumo 2004). The reduced mobility and flexibility of wildlife and livestock and curtailed access to distant pastures and water, amplify their vulnerability in times of drought, resulting in devastating impacts on herds (Western \& Nightingale 2003).

\section{AIMS, OBJECTIVES AND HYPOTHESES}

We update and extend previous analyzes of herbivore dynamics in Kajiado using aerial surveys conducted over the entire county from 1977 to 2011. All the earlier analyzes covered only either the Athi-Kaputiei or the Amboseli ecosystem. We analyze range contraction and expansion and spatial distinctions in declines in wildlife and livestock population densities. We infer the contributions of land use change and other anthropogenic factors to population dynamics after factoring out the contribution of rainfall variability. We expect wildlife and livestock numbers to fall during and soon after droughts but to rebound in the ensuing wet years (Western 1994, Mduma et al. 1999, Ogutu et al. 2003, Western et al. 2009) if rainfall, through its effect on vegetation, is the main cause of population change. We focus particularly on the population crash and rebound associated with the 2008-2009 drought. We evaluate evidence for displacement or competition between wildlife and livestock by relating wildlife density or aggregate population biomass to livestock density or aggregate biomass. We expect competition to be strongest between livestock and bulk grazers (e.g., buffalo, Syncerus caffer) and long-grass feeders (e.g., hartebeest, Alcelaphus buselaphus cokeii and waterbuck, Kobus defassa, Kassa et al. 2008), intermediate between livestock and mixed feeders (e.g., impala, Aepyceros melampus) and absent between livestock and pure browsers (e.g. giraffe, Giraffa camelopardalis). We also examine if changes in wildlife population density reflect spatial distinctions in the type and intensity of land use and density of settlements to separate out the effects of expanding human population pressures from those of rainfall variability. We expect cultivation and fencing of productive wetlands to have stronger adverse effects on the more water- dependent species (e.g. waterbuck) and bulk grazers (e.g. buffalo and elephants, Loxodonta africana) than on the less water-dependent species and short grass feeders. Rangeland fragmentation and loss of dispersal and migratory corridors should have a stronger negative effect on migratory and wide-ranging species.

\section{METHODS}

\section{Study Area}

We focus on the Eastern (Greater Amboseli) and Western Kajiado ecosystems because herbivore dynamics in the AthiKaputiei ecosystem have been recently documented (Reid et al. 2008; Ogutu et al. 2013; Said et al. 2013). The Greater Amboseli ecosystem consists of the Amboseli $\left(392 \mathrm{~km}^{2}\right.$, $\left.37^{\circ}-37^{\circ} 30^{\prime} \mathrm{E}, 2^{\circ} 30^{\prime}-2^{\circ} 45^{\prime} \mathrm{S}\right)$ and Chyulu Hills $\left(465 \mathrm{~km}^{2}\right)$ National Parks and 19 surrounding Maasai group ranches, collectively covering about $6032 \mathrm{~km}^{2}$. The two ecosystems consist of plains, valleys and volcanic hills and range in elevation from $500 \mathrm{~m}$ (asl) along the south-eastern border with Tsavo West National Park to $2500 \mathrm{~m}$ in the Ngong Hills area. The Amboseli ecosystem encompasses the lower slopes of Mt. Kilimanjaro (5896 m, asl) along the international border between Kenya and Tanzania that were formerly individual ranches but are now under cultivation, primarily rain-fed agriculture. The Amboseli National Park was officially gazetted in 1974. It was originally part of the Amboseli National Reserve $\left(3260 \mathrm{~km}^{2}\right)$ that was established in 1947 and became a Game Reserve in 1948. The park was declared a UNESCO World Heritage Site and a Man and Biosphere Reserve in 1991 owing to its rich habitat, large mammal and bird species diversity. The park lies within a shallow dried out Pleistocene lake basin $\left(1000 \mathrm{~km}^{2}\right)$ located $1200 \mathrm{~m}$ asl at the northern foot slope of Mt. Kilimanjaro on the Kenya-Tanzania border. The Amboseli basin is an internal drainage basin. Lake Amboseli $\left(140 \mathrm{~km}^{2}\right.$ ), though seasonal, receives regular water supply from River Namanga (Gichuki et al. 2001). The Amboseli basin consists of basement plains, saline plains with fresh water swamps and the volcanic slopes of Mt. Kilimanjaro. The basin contains three large and many small swamps fed by aquifers from Kilimanjaro (Western \& Maitumo 2004). The swamps and seasonal flooding make the basin an important and only permanent source of water in the ecosystem. Bordering the Amboseli ecosystem on the Tanzania side is the West Kilimanjaro region that encompasses extensive grazing lands and agricultural fields at lower elevations on Mt. Kilimanjaro. Agro-pastoral Maasai and other agricultural communities inhabit this area. The area also includes the Kilimanjaro National Park $\left(755 \mathrm{~km}^{2}\right)$, dominated by lowland forests.

\section{Group Ranches}

The Amboseli and Chyulu Hills National Parks are too small to support all the wildlife in the greater Amboseli Ecosystem (Sindiga 1995, Okello \& Kiringe 2004). Consequently, more wildlife are found outside than inside the protected areas (Western et al. 2009). Since the parks are not fenced, wildlife, including the migratory or wide-ranging wildebeest (Connochaetes taurinus), elephant, buffalo, zebra 
(Equus burchelli) and Thomson's gazelles (Eudorcas thomsoni) move seasonally among the parks, group ranches, community wildlife sanctuaries and other dispersal areas within the ca. $8000 \mathrm{~km}^{2}$ Amboseli ecosystem (Western 1975, 1982, Western \& Maitumo 2004). They congregate in the protected areas, especially Amboseli National Park with permanent swamps supplied by melt water and runoff from the nearby Mount Kilimanjaro and in other wetlands and riverine habitats in the dry season and disperse into the surrounding pastoral ranches in the wet season when water and forage are widely available (Western 1975, Andere 1981, Mworia et al. 2008). Maasai livestock are also allowed to enter Amboseli NP to access permanent water at midday in the dry season. The large grazers concentrate in areas of high grass cover or biomass within the parks while small herbivores concentrate in areas of low grass cover and biomass in the pastoral ranches in the dry season (Mworia et al. 2008).

The Amboseli group ranches constitute critical wildlife dispersal areas and migration corridors for wide-ranging wildlife species (Ntiati 2002, Okello \& D'Amour 2008), without which the protected areas would be isolated and insularized, with attendant increase in competition for the limited resources within their confines. The OlgululuiOlolorashi Group Ranch $\left(1232 \mathrm{~km}^{2}\right)$ that almost completely surrounds the Amboseli NP (90\%) and the Kimana group ranch $\left(297.9 \mathrm{~km}^{2}\right)$ that connects the Amboseli NP to Tsavo West National Park $\left(9,056 \mathrm{~km}^{2}\right)$ to the east are undoubtedly two of the most important wildlife dispersal areas and migration pathways (Okello \& Kioko 2010). The NamangaMagadi region $\left(5513 \mathrm{~km}^{2}\right)$ in Western Kajido currently contains eight additional group ranches.

\section{Diversification of Livelihood Options}

The Kajiado Maasai pastoralists are diversifying their livelihood options from subsistence pastoralism to reduce environmental risks and uncertainty and capitalize on new economic and social opportunities. These are presented by intensification of land use, land subdivision, sedentarization, climatic extremes and uncertainty, employment, trade, retail businesses and cultivation. Diversification is driven by (1) declining livestock numbers, productivity and profitability and outbreaks of zoonotic diseases linked to frequent droughts and shrinking land for pasture (Grandin 1991, Campbell 1993, Campbell et al. 2000, 2003, Southgate \& Hulme 2000, Seno \& Shaw 2002, Ogutu 2002, Okello 2005), (2) declining per capita livestock wealth, disillusionment with meagre returns from wildlife, changing lifestyles and food preferences (Western \& Nightingale 2003, Lamprey \& Reid 2004, Norton-Griffiths 2007, Homewood et al. 2009).

The pastoral land owners incur significant costs by maintaining national wildlife on their private land, which often far outweigh the actual benefits from wildlife. Yet, the Kenya government neither pays these costs nor compensates land owners for their contribution to wildlife conservation (Kabiri 2010). The Kenyan state also implements policies that reject government responsibility for wildlife damage to private property (Kabiri 2010). Most of the private land owners lack control, ownership and use rights over wildlife as well as financial incentives to conserve wildlife on their lands (Norton-Griffith \& Said 2010). These policies prevent the land owners from maximizing returns from wildlife (Thompson \& Homewood 2002, Norton-Griffiths 2007, Norton-Griffiths \& Said 2010). As a result, wildlife is economically uncompetitive across most of Kenya's rangelands and unable to pay the high costs of conservation. These glaring policy, legal, institutional and market failures undermine wildlife conservation goals (Norton-Griffiths 1998, Norton-Griffiths \& Said 2010, Shikwati 2003). Where wildlife generates benefits on protected and pastoral lands, very little is invested in conservation, very few rural households receive these benefits, but even the few who do receive meager benefits (Homewood 2009, Norton-Griffiths $\&$ Said 2010). The bulk of the wildlife benefits accrue almost exclusively to the national and county governments, the tourist industry and a few powerful elites with disproportionately greater access to and control of revenue streams flowing from wildlife (Thompson \& Homewood 2002). Ironically, the costs are borne wholly by the pastoral communities, causing deep resentment of wildlife (Thompson \& Homewood 2002). The poor pastoral land owners become poorer by supporting wildlife, tourism and ecotourism enterprises on their lands and enriching a few powerful elites. Their land use decisions are therefore understandably less likely to favour conservation (Homewood 2009).

\section{Socio-cultural Transformation, Governance and Policy}

Since the 1880 s approaches to conservation of wildlife in Kenya, as in most other parts of Africa, have been driven by outsiders with predominantly western world views, principles, philosophies and finance (King 2011). The intricate, well developed and distributed traditional governance of resources by the indigenous people, such as the Maasai, were thus replaced with centralized authority based on political power and government decisions often made through fiat rather than negotiation, consultation and consensus (Noe 2003, Western \& Nightingale 2003). This alienated the indigenous people from wildlife (Sen 1981, Chambers 1997, Kaka 2011). The Kenya Wildlife Service (KWS) and county governments mandated to manage wildlife have been utterly unable to fulfill their roles outside the state owned protected areas. They lack enabling legislation, representation or presence on the privately owned pastoral lands. This has created a management vacuum, which, together with lack of access, control, ownership rights, or incentives to conserve, has created room for overexploitation of wildlife and destruction of their habitats (Juma 1989, King 2000, Nelson 2010). The failure of the national government to liberalize wildlife policies despite its inability to provide sufficient management and other resources to conserve, protect and manage wildlife and their habitats in the pastoral lands has imperiled the future of wildlife in Kenya (Western 2002). Ineffective coordination of the implementation of the national economic, agricultural and settlement policies with policies on tourism and wildlife conservation (Campbell et al. 2000) has permitted land uses incompatible with pastoralism, wildlife conservation and tourism on the pastoral lands. Strong vested interests, intense contests for wildlife benefits, low transparency and accountability, weak regulations and law enforcement, and endemic corruption, have generated mismatches between the 
intended and realized outcomes of wildlife conservation policies on the pastoral lands (Homewood 2009).

\section{Land Use and Human-Wildlife Conflicts}

Land use and human-wildlife conflicts arising from incompatible land uses and shrinking space are amplified by droughts that intensify competition for water between domestic users, cultivators, livestock and wildlife; and for pasture between livestock and wildlife. Conflicts arise when wildlife damage crops, fences and water pipes and transmit diseases to livestock, disturb, threaten, injure or kill livestock or people. Conflicts also arise when problem wildlife are harassed, harmed or killed in retaliatory attacks; livestock are grazed in parks and areas used by tourists, or when wildlife movements are impeded (Sindiga 1999, Serneels \& Lambin 2001, Gadd 2005, Kioko et al. 2006 a, b, Norton-Griffiths 2007, Meguro and Inoue 2011). The conflicts increase when wildlife numbers increase or when animals lose their fear of people. Lack of user rights, inequitable sharing of wildlife revenue, lack of compensation for losses caused by wildlife and community exclusion from wildlife conservation further aggravates the conflicts (Okello 2005).

Wildlife has therefore become a burden rather than relief for the pastoral land owners during droughts. Rising conflicts increase the polarization of land use as wildlife are compressed within the protected areas by anthropogenic impacts (Campbell et al. 2000, Worden et al. 2003, Okello et al. 2005, Okello 2005, Okello et al. 2009). The conflicts strain tolerance for wildlife among the Maasai, even though most of them still support wildlife conservation (Okello 2005). The stage is set for even deeper conflicts as pressures on the land continue to build up and tolerance of wildlife falls. The grievances and conflicts promote persecution of wildlife and adoption of land uses incongruent with wildlife conservation (Okello 2005).

\section{Habitat Types}

Kajiado is mostly (80\%) an arid to semi-arid savanna. The main habitats types in Amboseli ecosystem are open grass plains, acacia woodlands, rocky thorn bush lands, swamps and marshlands (Ecosystems Ltd. 1982, Boone et al. 2005). Permanent wetlands cover about $2 \%\left(421 \mathrm{~km}^{2}\right)$ of Kajiado (Gichuki et al. 2001). These wetlands plus seasonal rivers, artificial boreholes and water dams are the main sources of water for humans, livestock and wildlife (Gichuki et al. 2001). Livestock graze in wetlands in the dry season when nutritious forage and water are depleted in upland areas but return to the uplands in the wet season when the lowland wetlands become flooded. The major wetlands in the County are threatened with siltation, excessive water abstraction for irrigation, urban and industrial uses and pollution from agrochemical residues (Gichuki et al. 2001). This has greatly reduced riverine and swamp habitats downstream, depleting grazing lands and drought pastures. Poorly developed and shallow clayey soils, including black clayey (grumosolic) soils composed of calcareous and noncalcareous variants of "black cotton" soils susceptible to waterlogging dominate the floodplains. Soils are alkaline and locally saline and highly susceptible to erosion in the Amboseli basin (Western 1973). Brown calcareous clay loams, sandy soils, ash and pumice soils dominate at higher elevations (Ole Katampoi et al. 1990). Basement rock soils cover large areas making only pastoralism possible in most parts of the county (Pratt \& Gwynne 1977).

\section{Major Land Uses}

As Kajiado is mostly arid to semiarid, it has low agricultural potential. As a result, the main land uses in the County are pastoralism $\left(4981 \mathrm{~km}^{2}\right)$, wildlife conservation in public protected areas $\left(874 \mathrm{~km}^{2}\right)$ and private conservancies $\left(143 \mathrm{~km}^{2}\right)$, rain fed $\left(415 \mathrm{~km}^{2}\right)$ and irrigated $\left(72 \mathrm{~km}^{2}\right)$ agriculture in well-watered areas (swamps and riparian zones) and highlands. Irrigated horticulture has expanded rapidly in riparian zones in recent decades stimulated by economic liberalization and improved access to national and international markets (Campbell et al. 2000; NortonGriffiths \& Butt 2003). Most perennial swamps at the base of Mt. Kilimanjaro, woodlands and riverine vegetation have been cleared for cultivation in the last three decades, severely decreasing the dry season wildlife habitats (Ogolla \& Mugabe 1996, Kioko et al. 2008, Kioko \& Okello 2010). Quarrying of building stones and sand harvesting on dry river beds further degrade wildlife habitats.

\section{Vegetation Changes}

Woodlands and bush lands have declined sharply whereas grasslands, scrublands and swamps have expanded inside the parks over the past half a century due to destruction of woodlands by increasing elephant densities (Western \& Maitumo 2004, Western 2007). Inside parks, high elephant densities create open grasslands, dominated by grazing ungulates and prevent woodland recovery. Outside, year-round settlement due to a shift from nomadic pastoralism to sedentarisation by the Maasai and heavy livestock grazing since the mid-1970s, and exclusion of large browsers such as elephants create ideal conditions for seedling growth, resulting in the conversion of grasslands to bush lands and dense woodlands favoured by browsing ungulates (Western \& Maitumo 2004). Further, human activity deters elephants, enabling woodlands to regenerate rapidly outside the park. Consequently, livestock cross into the park to feed on the new grasslands and elephants move outside to browse the new woodlands. Livestock incursion into the Amboseli Park is accentuated by the scarcity of water in the area surrounding the park in the dry season. The declining woodland cover due, in part, to clearing of natural vegetation for cultivation, building settlements and thorn fences, fuel wood and charcoal burning (Western \& Maitumo 2004, Okello \& Kioko 2010) progressively depletes habitat and large mammal diversity.

\section{Rainfall and Droughts}

Rainfall is the key climatic component governing vegetation growth and production (Deshmukh 1984, Boutton et al. 1988) and animal population abundance, biomass and dynamics (Coe et al. 1976, East 1984, Fritz \& Duncan 1994) in African savannas. Rainfall is low, bimodal and highly variable across the county, with the annual component averaging $685 \mathrm{~mm}$ (range $327-1576 \mathrm{~mm}$ ). The short rains fall during November-December $(30.97 \pm 27.85 \%$ of the annual total) and the long rains during March-May (47.5 \pm $15.06 \%$ of the annual total). The dry season spans June- 
September (Fig. 2a). Rainfall is highly variable in space and increases with altitude from $300 \mathrm{~mm} / \mathrm{yr}$ in the low-lying Amboseli basin up to $1250 \mathrm{~mm} / \mathrm{yr}$ on the slopes of Mt. Kilimanjaro and Chyulu Hills (Moss 2001) in the south east to $800 \mathrm{~mm}$ in Nairobi Park and $971 \mathrm{~mm}$ at Ngong hills in the northwest. Droughts are frequent, prolonged and often associated with failure of the short rains. Severe droughts occurred during 1933-1935, 1943-1946, 1948-1949, 19521953, 1960-1961, 1972-1976, 1983-1984 and 1994-1995 in the $20^{\text {th }}$ century (Campbell 1999) and during 2005-2006 and 2008-2009 in the $21^{\text {st }}$ century. The severest droughts since 1960 occurred in 1960-1961, 1983-1984, 1999-2000 and 2008-2009. The severity of drought impacts varies with both rainfall and animal stocking rates. Temperatures range between $12{ }^{\circ} \mathrm{C}$ and $34{ }^{\circ} \mathrm{C}$, are coolest in July-August and hottest in November-April (Berger 1993). Both the minimum (by $1.81 \pm 0.46^{\circ} \mathrm{C}$ between 1961 and 2013) and maximum $\left(0.275^{\circ} \mathrm{C}\right.$ per annum between 1976 and 2001) temperatures are rising in the County (Altmann et al. 2002, Ogutu et al. 2013).

\section{METHODS}

\section{Rainfall Measurements}

Rainfall records were provided by the Kenya Meterological Department for the following 12 locations within Kajiado County: Kajiado District Commissioner's Office (1960-2000), Kajiado Maasai Rural Training Centre (1962-2010), Konza Railway Station (1960-2002), Konza Ranch Office (1970-1996), Namanga Health Centre (19602000), Ngong Divisional Office (1960-2006), Ngong Forest Station (1970-2011), B \& T Malinda Ranch-Lukenya (19702010), Entasopia Youth Polytechnic (1970-1999), Loitokitok Outward Mountain School (1970-1994), Magadi Soda Works Labs (1959-1991) and Stony Athi Railway Station (1970-1994).

The total monthly rainfall records were averaged over all the 12 stations prior to analysis. The mean monthly rainfall displays a major peak in April during the long rains received in March-May, and a minor peak in November during the short rains covering November-December (Fig. 1A). We computed the annual (October-September), wet (OctoberMay) and dry (June-September) season rainfall components. Mean annual rainfall (October-September) varied spatially from $313.3 \mathrm{~mm}$ (range 103.8-609.4 mm) at Stony Athi Railway Station to $979.6 \mathrm{~mm}$ (range 466.6-1947.0 mm) at Ngong Forest Station. We also computed 1 to 5-year moving averages of the annual rainfall for use in exploring the influences of prior rainfall potentially affecting habitat conditions on population trends (rainfall data provided in supplementary materials A). The 5-year window was selected to represent phases of the regional quasi-periodic rainfall oscillation (Ogallo 1982, Nicholson \& Kim 1997, Ogutu et al. 2008).

\section{Aerial Surveys}

The Department of Resource Surveys and Remote Sensing of Kenya (DRSRS) conducted 17 aerial sample surveys of wildlife and livestock from 1977 to 2011 over the entire Kajiado County. The counts in Amboseli ecosystem covered $7730.32 \mathrm{~km}^{2}$, divided into UTM grids measuring $5 \mathrm{~km}$ on a side except in 1977 when $10 \mathrm{~km}$ and October 1994 when $2.5 \mathrm{~km}$ grids were used. Each $5-\mathrm{km}$ transect segment was treated as an observation. Systematic transect lines were flown through the centre of each grid on a northsouth axis at a nominal height of 90-91 $\mathrm{m}$ above ground. Widths of counting strips averaged $296.7 \pm 60.2 \mathrm{~m}$ (range 224-490 m). Within each strip, rear-seat observers counted all wild and domestic animals the size of Thomson's gazelle (25 kg) and larger and recorded all counts on tape recorders. Animal herds too numerous to count by eye (often >10) were photographed and later counted under a binocular microscope. The coordinator and front seat observer recorded environmental data. The sample fraction averaged $5.7 \pm 1.6 \%$ of the total counting area. The Amboseli Conservation Programme also conducted aerial surveys covering the entire Amboseli ecosystem $\left(8300 \mathrm{~km}^{2}\right)$ in February and October 2010 using the DRSRS procedure and two experienced DRSRS observers (Worden et al. 2010a). Furthermore, the Kenya Wildlife Service (KWS) conducted an attempted aerial total count covering the $8300 \mathrm{~km}^{2}$ Amboseli ecosystem plus an additional $497 \mathrm{~km}^{2}$ in March 2010. The counts were flown in a Cessna 206 aircraft. Reliability of the DRSRS counts has been demonstrated by multiple calibrations (Ottichilo \& Khaemba 2001). Population estimates (PE) and standard errors (SE) for each species for the Amboseli and Western Kajiado ecosystems (provided in Supplementary Materials B) were calculated from the sample fraction by treating each transect as a sample unit using Jolly's Method 2 (Jolly 1969, NortonGriffiths 1978) as $P E=N \bar{y}$ and $S E=\sqrt{\frac{N(N-n) s^{2}}{n}}$ where

$\bar{y}$ is the sample mean, $s^{2}$ is the sample variance, $n$ is the sample size, and $N$ is the number of observations required to fully cover the study area. Since the transect lines are systematically distributed in space, the surveys also give spatial distributions of wildlife and livestock. More elaborate accounts of the survey methodology can be found elsewhere (Pennycuick \& Western 1972, Norton-Griffiths 1978, Western et al. 2009).

\section{Mapping Land Use and Settlements in Kajiado}

We derived land use classes based on map 8 of the LUCIDILRI Working paper series number 34 of November 2013 (Available at http://www.lucideastafrica.org/public-ations.htm). We used Africover FAO land cover of 2000 reclassified into eight land use/cover types. The resulting GIS layer was united with the layer for Game Parks extracted from the World Database on Protected Areas (WDPA) and all the areas covered by parks and forest reserves classified as National Parks and Forest Reserves, respectively. The resulting GIS layer was united with the layer for wildlife conservancies produced by the Kenya Conservancies Association and the areas covered by conservancies classified as conservancies. This resulted in a file with all the eight land use classes, namely pastoral livestock herding, irrigated agriculture, rain fed agriculture, conservancies, national parks, forest reserves, urban areas and associated 

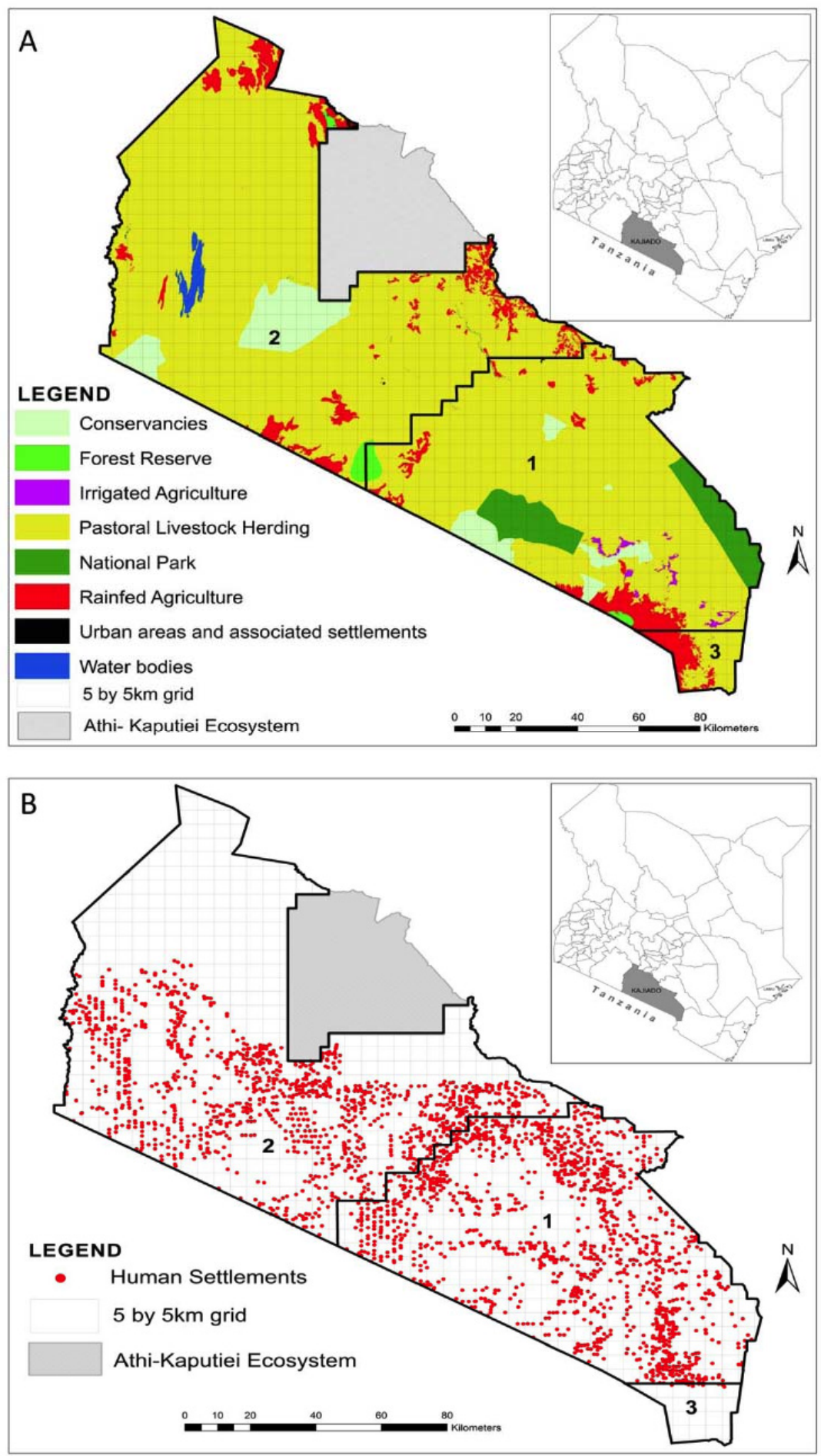

Fig. (1). Map of Kajiado County of Kenya showing A) Loitokitok (3), Eastern (1) and Western (2) parts of the County. Also shown are eight land use types and the $5 \times 5 \mathrm{~km}$ grid used by the Department of Resource Surveys and Remote Sensing for aerial surveys and the Athi-Kaputiei Ecosystem. B) The distribution of human settlements in parts of Kajiado County in 2010.

settlements and water bodies. The total area of each of the 5 by $5 \mathrm{~km}$ DRSRS survey units covered by each land use type was then calculated by intersecting the preceding land use file with the file containing the survey units. The resulting file was clipped at the edges to match the boundaries of Eastern and Western Kajiado. The total area covered by each land use type was then calculated. The resulting file was linked to the file containing the DRSRS wildlife and livestock counts at a 5 by $5 \mathrm{~km}$ resolution.
Data on human settlements in Kajiado were obtained from the aerial survey conducted by both the Kenya Wildlife Service and the Tanzania Wildlife Research Institute with support from the African Wildlife Foundation, Amboseli Trust for Elephants and Tanzania National Parks in March 2010. These data consisted of spatial point features with several attribute values, including houses with different roof types. The information, at a spatial resolution of 5 by $5 \mathrm{~km}$, was linked to the DRSRS survey units using the Identify 
function in ARC GIS Version 10 (ESRI 2011) and the resulting file clipped to match the boundaries of Eastern and Western Kajiado. The total number of settlements was calculated for each 5 by $5 \mathrm{~km}$ survey unit. The resulting file was joined to the file containing the DRSRS wildlife and livestock survey data.

\section{STATISTICAL ANALYSES}

\section{Rainfall}

Deviations in rainfall from the long-term mean were quantified and used to classify years as extreme, severe or moderate drought years, normal, wet, very wet or extremely wet years, depending on whether the annual rainfall total fell within the $0-10,11-25,26-40,41-75,76-90,91-95$ and $96-100^{\text {th }}$ percentiles of the frequency distribution of annual rainfall, respectively (Ogutu et al. 2008). The wet and dry season components were similarly classified. The percentiles enabled characterization of seasons and years in terms of the intensity of the deviation of rainfall from its long-term mean and the consequent broad transitions in rainfall effects on vegetation production and forage quality.

\section{Modeling Population Trends}

We analyzed trends for wildlife and livestock population estimates for the entire Kajiado County and for the greater Amboseli Ecosystem using a flexible multivariate semiparametric generalized linear mixed model with a negative binomial error distribution and a log link function. The model allows for non-normality of the frequency distribution of the counts and nonlinearity of time trends in the population estimates, the varying frequency of surveys and the variation in the variance of the population estimates with the mean. The model accounts for the common trend pattern shared by all the species and the trend patterns specific to individual species. The model uses cubic B-spline (Eilers \& Marx 1996) smoother covariance structure with equidistant (10 to 20) interior knots placed on the running time of survey (February 1977,..., November 2011) and random spline coefficients, with a cubic difference penalty on the B-spline coefficients. The computation and properties of B-splines is detailed in De Boor (2001). The smoother derives from the automatic smoother described in Ruppert et al. (2003, Chapter 13.4-13.5). We used two continuous random spline effects (running time of aerial survey) to define the multivariate smoother in the SAS GLIMMIX procedure (SAS Institute 2013). One continuous random spline effect modeled the trend common to all the species, whereas the other specified the species-specific trends. Livestock trends were likewise, but separately modeled. Further details on the multivariate penalized spline smoother are provided in Ogutu et al. (2011, 2012).

\section{Relating Wildlife and Livestock Biomass to Rainfall}

We correlated the combined wildlife and combined livestock biomass densities with moving averages of annual rainfall computed over time windows spanning 1, 2, 3, 4 or 5 years. We also correlated the wildlife biomass density with livestock biomass density and interpreted negative correlations as indicating competition or spatial displacement.

\section{Mapping Changes in Spatial Distribution of Wildlife and Livestock}

Since the counts in each sampling unit are a very small sample of the total count area, they vary markedly between years. Thus, we averaged the counts for each species in each counting unit over several years in each decade to reduce the variance and establish how animal density changed over time and space. 1) We added up all the individuals of each species counted in each unit and divided the total by the sampling fraction and area of each unit to obtain a density estimate for each species in each unit and survey combination. 2) We next calculated the average density of each species in each unit across all surveys conducted in each decade (1970s, 1980s, 1990s and 2000s). 3) We also calculated the average density of each species in each unit across all surveys. 4) For all units with non-zero mean density over all surveys, we further computed the $25^{\text {th }}, 50^{\text {th }}$ and $75^{\text {th }}$ percentiles of density for each species. The density of each species in each unit was then recoded in terms of the percentiles as follows. 5) The mean density for each species in each unit was set to zero for all the decades if the overall mean density for the species in the unit was zero. 6) But the mean density for each species in each unit was set to the $25^{\text {th }}$ percentile for the decade if the mean density for the unit in the decade was greater than zero but did not exceed the $25^{\text {th }}$ percentile of density for the unit across all the surveys. 7) However, the mean density for each decade was set to the median density for all surveys if the $25^{\text {th }}$ percentile of density for a given unit over all surveys was less than the mean density for the unit in a given decade but the decadal mean density did not exceed the median density for the unit over all surveys. 8) Lastly, the decadal mean density was set to the $75^{\text {th }}$ percentile of density for all surveys if the median density for a given unit over all surveys was less than the mean density for the unit in a given decade but the decadal mean density was less than or equal to the $75^{\text {th }}$ percentile of density for the unit over all surveys.

The recoded densities were plotted for each species in each unit against the UTM coordinates for the center of each unit in each decade. A different colour scheme was assigned to each of the four density categories in each decade and the same colours used for all the four decades to visualize how the density of each species changed in each unit between the decades. The same scale and colour schemes were used for the maps for all the four decades to directly compare the varying levels of density for the same species over time and identify the spatial location and type of change.

\section{Relating Wildlife and Livestock Trends to Land Use and Settlements}

We averaged the density of each animal species estimated for each $5 \times 5 \mathrm{~km}^{2}$ survey unit separately across each of the three surveys spanning 1977-1980 and 20062011 periods, considering only those units sampled in both periods. We next averaged the density of each animal species across all the $5 \times 5 \mathrm{~km}^{2}$ units sampled in each land use type during 1977-1980 and 2006-2011 separately for Eastern and Western Kajiado. We summed all the settlements and the total area covered by each land use type in each ecosystem during 1977-1980 and 2006-2011. We then compared the mean density of each species between land use types and 


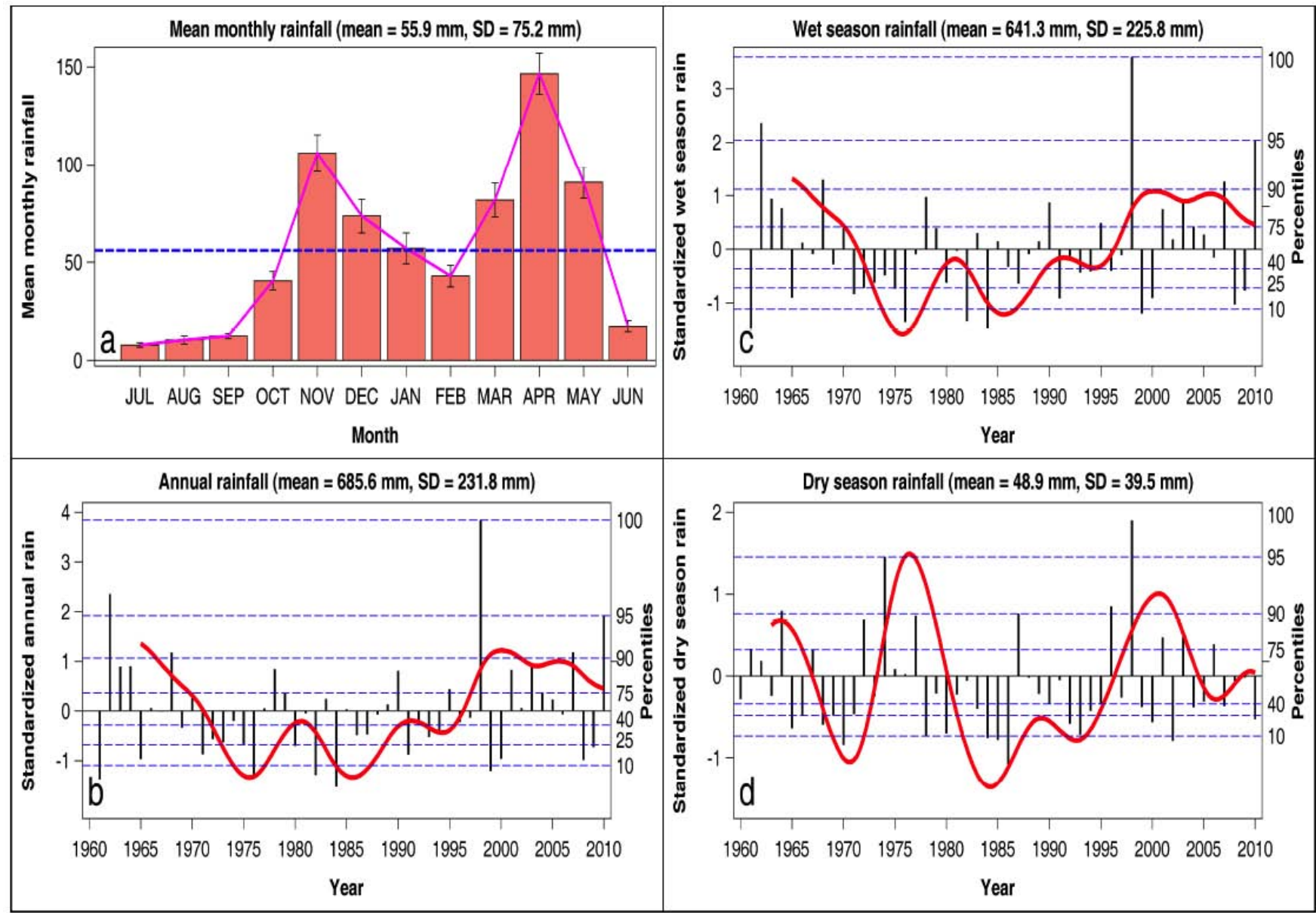

Fig. (2). The mean monthly (a), standardized annual (b), wet (c) and dry (d) season rainfall (1960-2011). The total monthly rainfall was averaged over 12 stations. Dashed horizontal lines are the 10, 25, 40, 50, 75, 90, 95 and $100^{\text {th }}$ percentiles of the frequency distribution of rainfall normalized to zero mean and unit variance. Solid lines are the 5-year moving averages of rainfall components. Needles are the normalized rainfall values.

periods separately for each ecosystem. We also analyzed changes between the two periods in the average density of each species calculated across all survey units with an average density of settlements failing within the $0^{\text {th }}, 25^{\text {th }}$, $50^{\text {th }}, 75^{\text {th }}$ and $>75^{\text {th }}$ percentiles of the distribution of settlement density regardless of land use type.

\section{RESULTS}

\section{Trends in Rainfall}

Monthly rainfall was markedly bimodal, averaged $80.1 \mathrm{~mm}$ (range $0-391.8 \mathrm{~mm}$ ) in the wet season and $12.0 \mathrm{~mm}$ (range 0-118.5 mm) in the dry season, and was highly variable (dry season $\mathrm{CV}=121.8 \%$ and wet season $\mathrm{CV}=83.7 \%$, Fig. 2a). On average the dry season rainfall (June-September) contributed merely $6.9 \%$ (range 1.0$17.0 \%$ ) to the annual total. Annual, dry and wet season rainfall components varied markedly in Kajiado and showed 5-year quasi-periodicity during 1960-2010. During 19602010 extreme droughts occurred in 1961, 1976, 1982, 1984 and 1999 whereas severe droughts occurred in 1965, 1971, 1975, 2000, 2004, 2006, 2008 and 2009. By contrast, 1962 and 1998 were extremely wet due to the Indian Ocean
Dipole and El Niño rains (Saji et al. 1999, Webster et al. 1999), respectively. In addition, 1968 and 2001 were very wet years (Fig. 2b). The wet season rainfall was lower than average during 1972-1980 but higher than average during 1990-2010 (Fig. 2c). The dry season rainfall was, however, lower than average during 1966-1973 and 1980-1990 but exceeded the average during 1974-1979 and 2002-2009 (Fig. 2d).

\section{Trends in Wildlife and Livestock Numbers}

Between 1977 and 2011 the population size of all the wildlife species in Eastern Kajiado but elephant decreased markedly by between $13 \%$ and $89 \%$ (Fig. 3). Except for hartebeest, T. gazelle, warthog (Pharcocoerus africanus), waterbuck and oryx (Oryx beisa) whose numbers decreased persistently during the monitoring period, the other 10 wildlife species maintained stable average numbers from 1977 before dropping precipitously in the 2008-2009 drought (Fig. 3). All the wildlife species showed upward trends in 2011, signalling population rebound from the 2008-2009 drought. Elephant numbers more than doubled in Eastern Kajiado from an expected 489 animals in 1977-1979 to 1049 animals in 2010-2011, an increase of $114.8 \%$ (Fig. 3). Likewise to wildlife, livestock numbers also declined in Eastern 

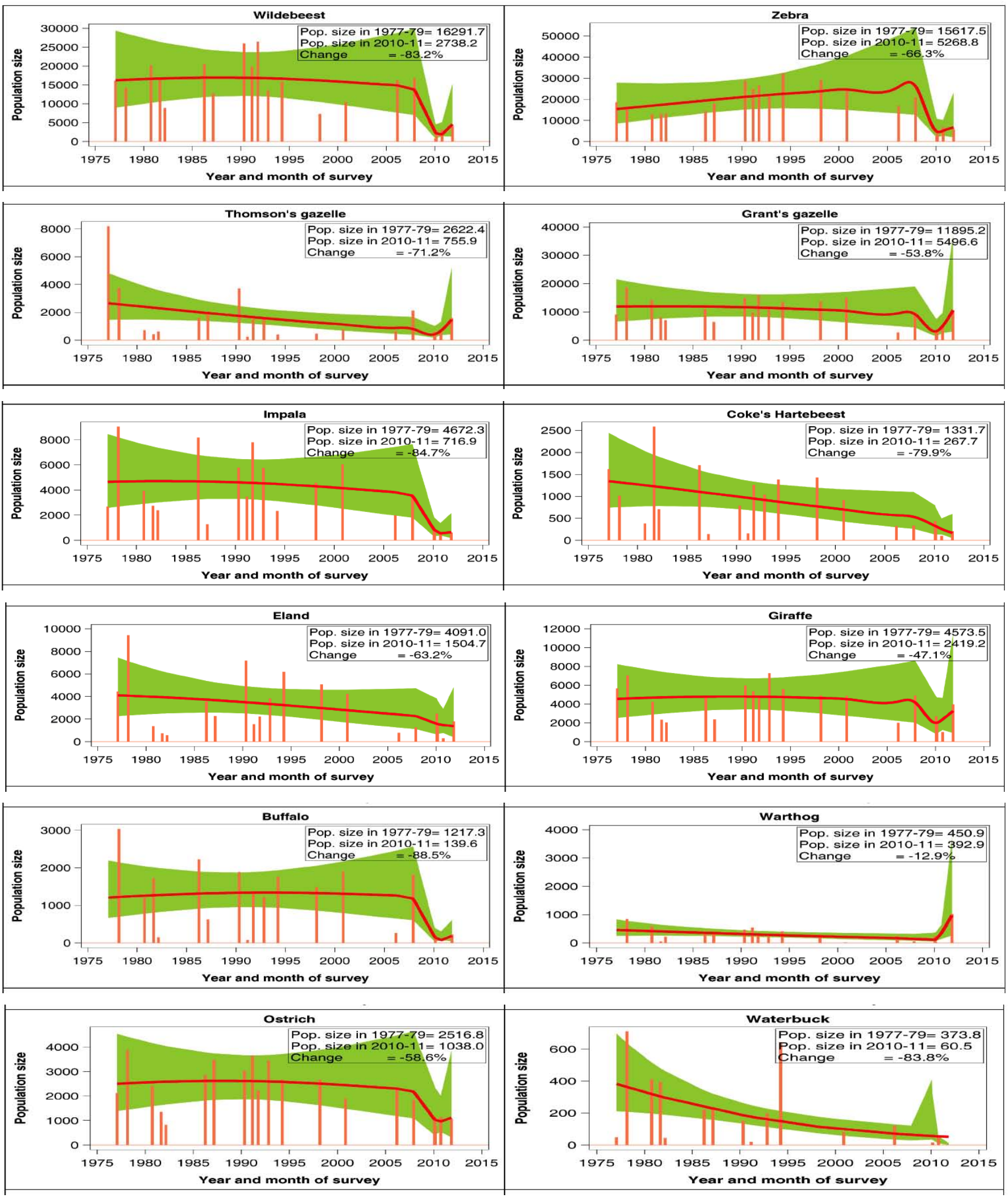

Fig. (3). Contd... 


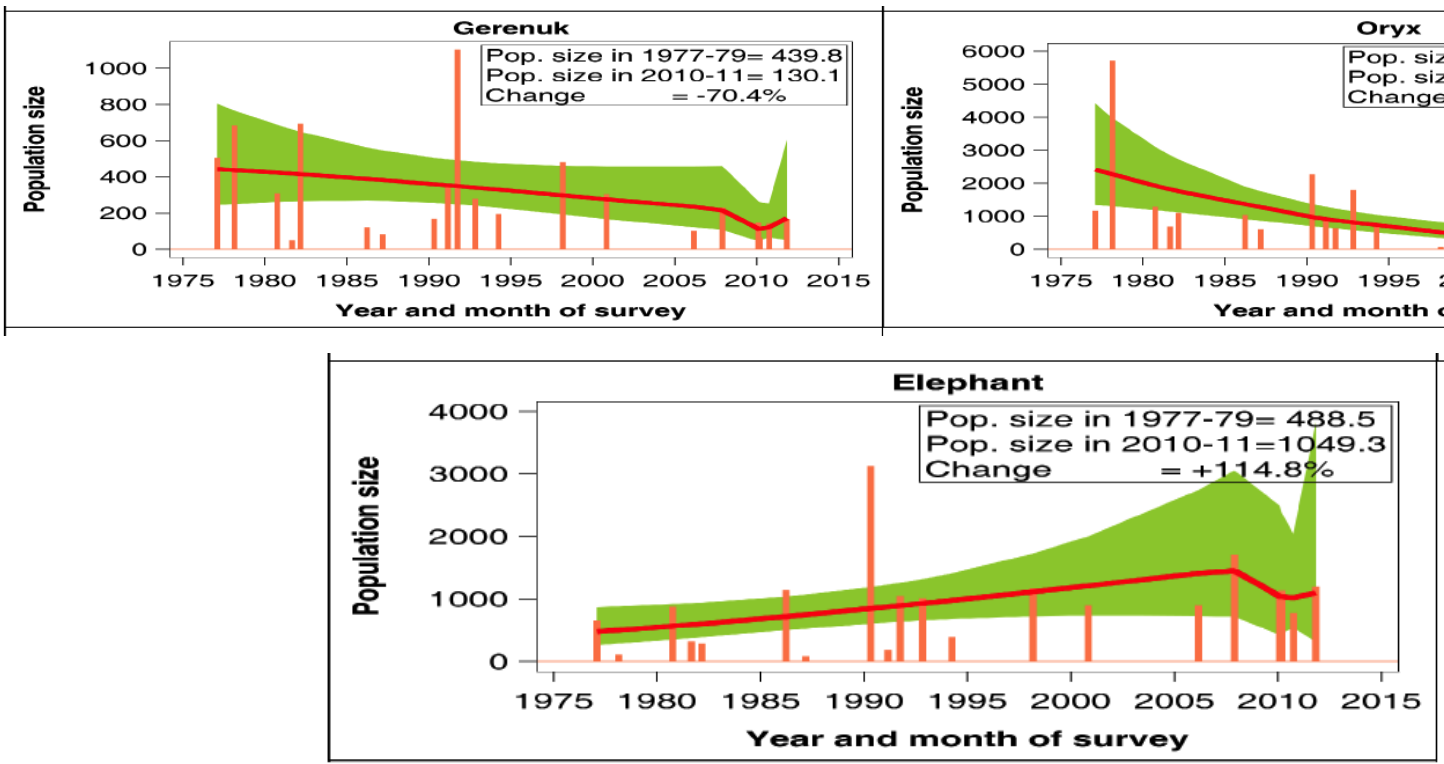

Fig. (3). The estimated population totals (needles) and the fitted trend lines for 14 ungulate species and ostrich in the Greater Amboseli Ecosystem based on aerial surveys conducted by the Department of Resource Surveys and Remote Sensing of Kenya (DRSRS) during 19772011. The shaded region is the $95 \%$ confidence band of the fitted trend curve.

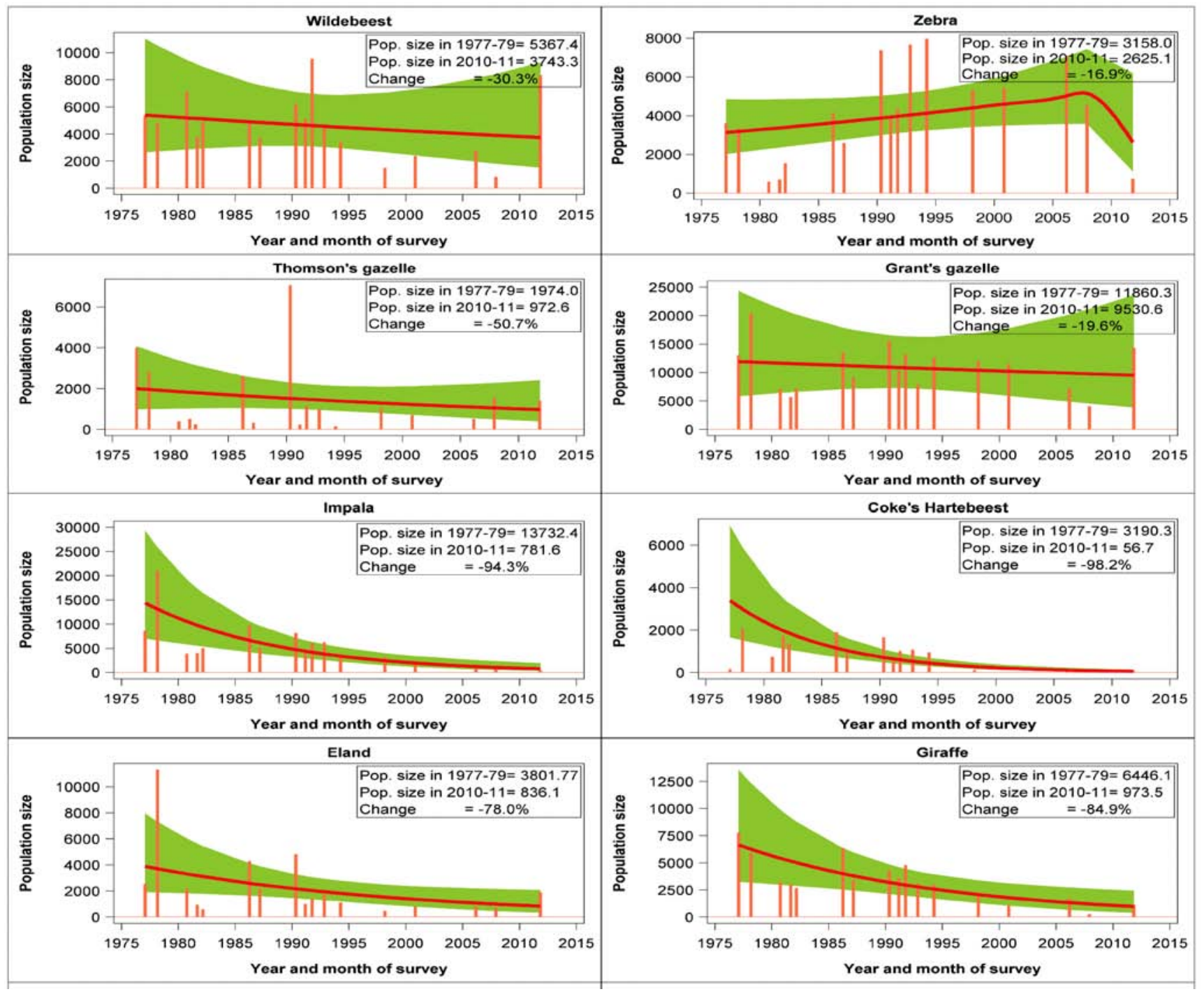

Fig. (4). Contd... 

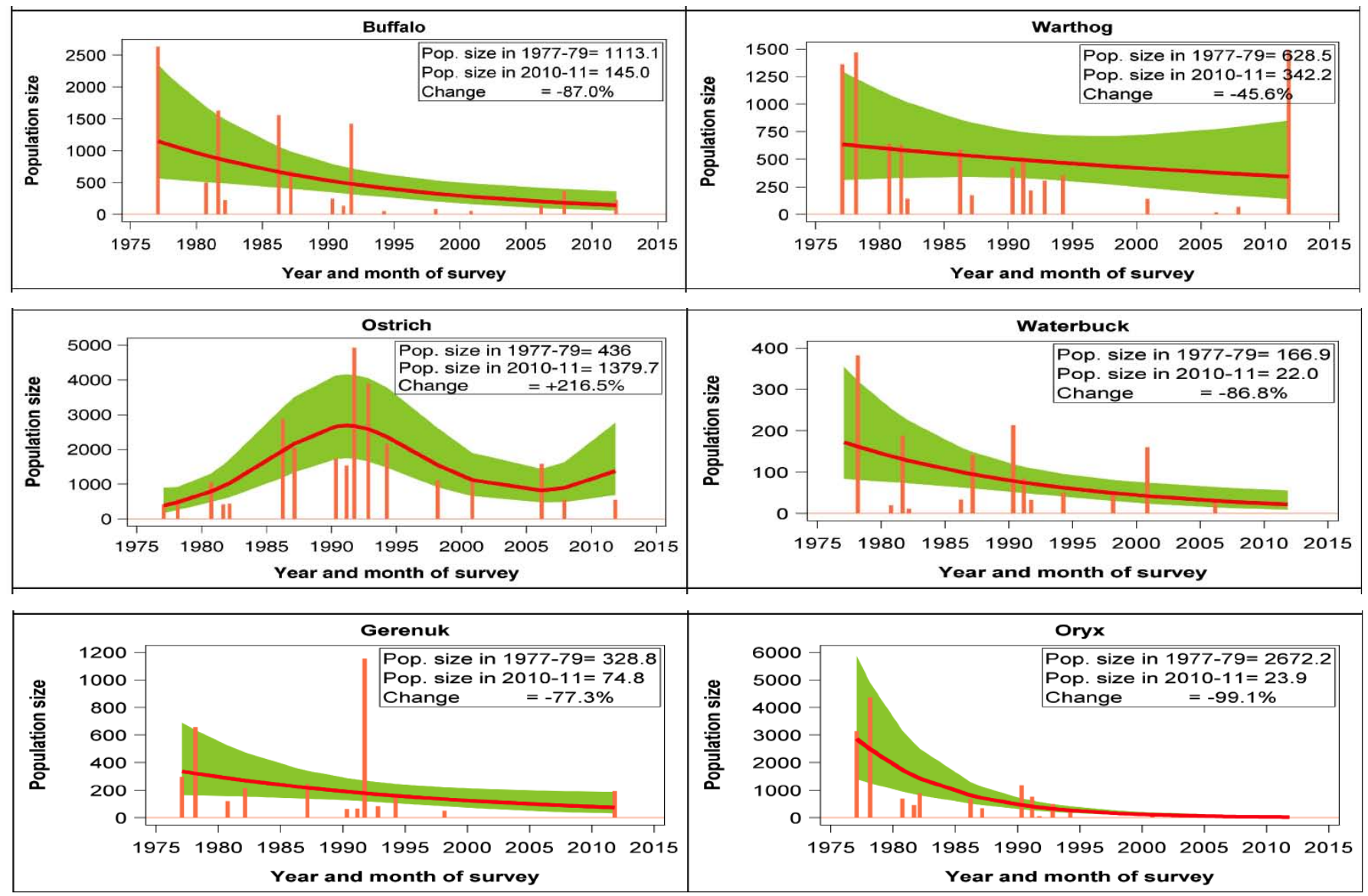

Fig. (4). The estimated population totals (needles) and the fitted trend lines for 13 ungulate species and ostrich in Western and Central Kajiado based on aerial surveys conducted by the Department of Resource Surveys and Remote Sensing of Kenya (DRSRS) during 19772011. The shaded region is the $95 \%$ confidence band of the fitted trend curve.confidence band.

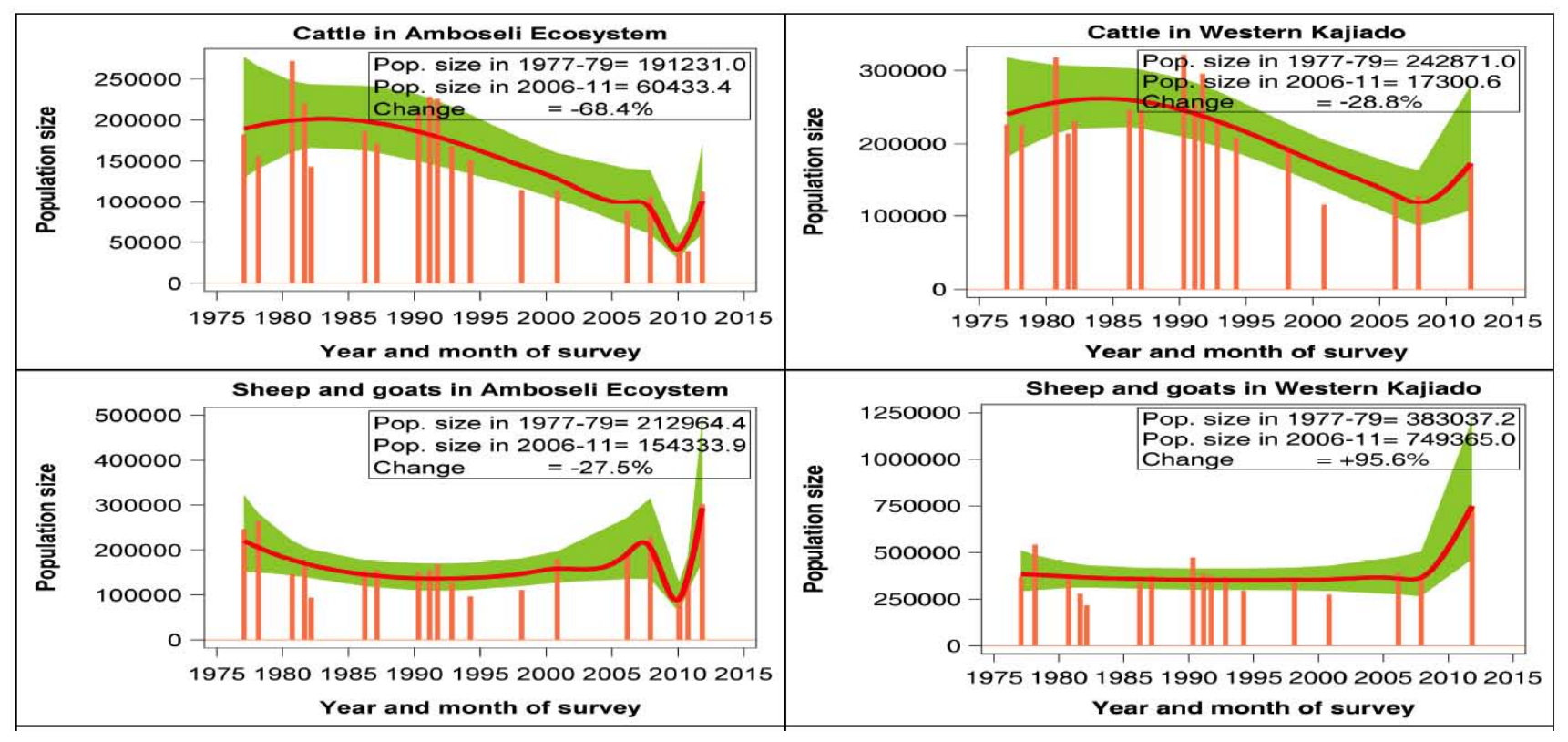

Fig. (5). Contd... 


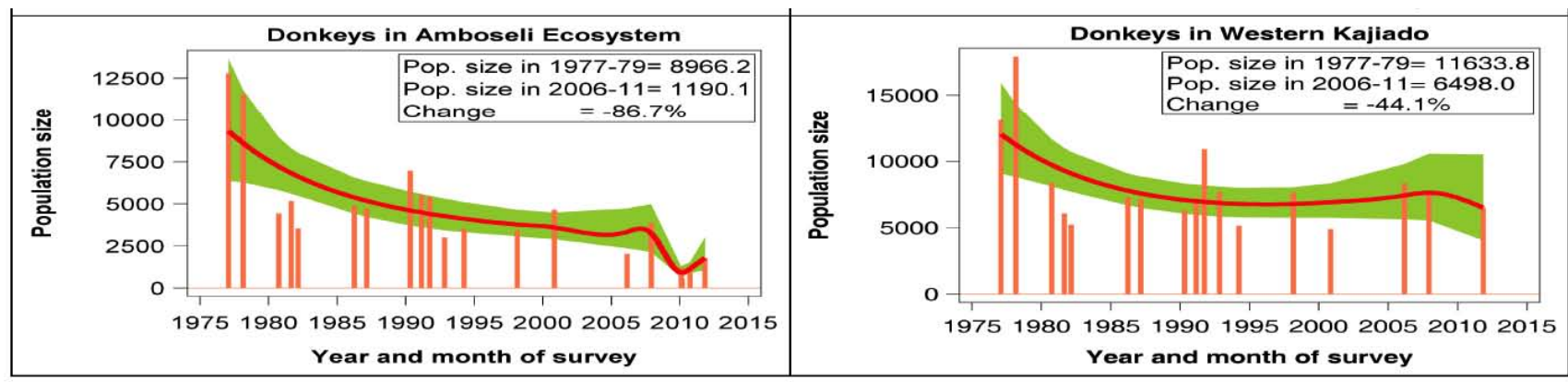

Fig. (5). The estimated population totals (needles) and the fitted trend lines for livestock in Kajiado County based on aerial surveys conducted by the Department of Resource Surveys and Remote Sensing of Kenya (DRSRS) during 1977-2011. The shaded region is the 95\% confidence band of the fitted trend curve.
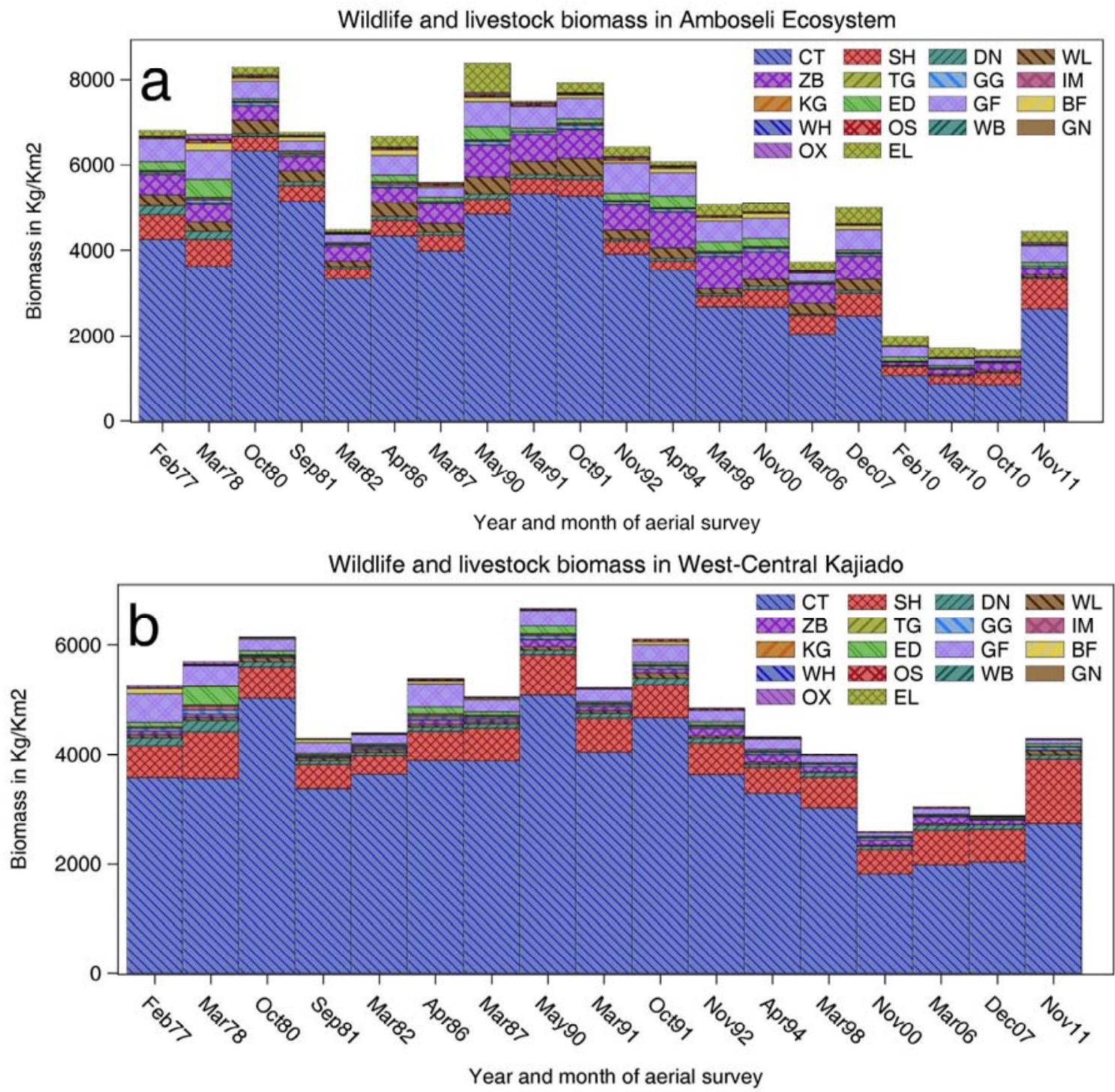

Fig. (6). Temporal trend of the cumulative biomass of wildlife and livestock species occupying the (a) Greater Amboseli Ecosystem and (b) Western Kajiado during 1977-2011.

Kajiado by between 27.5 and $86.7 \%$ (Fig. 4). The numbers of all the wildlife species showed generally declining trends, evidence of massive mortality during the 2008-2009 drought, and upward trends from 2010, indicating population recovery. In Western Kajiado, wildlife numbers also declined strikingly, with zebra, impala, eland (Taurotragus oryx), buffalo, gerenuk (Litocranius walleri), hartebeest, giraffe, waterbuck and oryx numbers declining by between $77 \%$ and $99 \%$. Numbers of wildebeest and both gazelles also declined but at lower rates than in Eastern Kajiado (Fig. 5). Cattle and donkey numbers decreased but at approximately half the rates recorded for Eastern Kajiado whereas numbers of sheep and goats had surprisingly nearly doubled two years after the 2008-2009 drought (Fig. 6). 


\section{Trends in Livestock and Wildlife Biomass}

Livestock dominated the aggregate herbivore biomass, contributing $70-80 \%$ of the total biomass throughout the 1977-2011 monitoring period in both regions of the County (Fig. 6a and b). Wildlife constituted $24.3 \%$ of the combined livestock and wildlife biomass in the county in the 1970 s, $15.6 \%$ in the $1980 \mathrm{~s}, 21.9 \%$ in the $1990 \mathrm{~s}$ and $24.9 \%$ in the 2000s.

Cattle contributed most of the livestock biomass followed by sheep and goats, reflecting their significance to the pastoral Maasai economy. The proportional contribution of sheep and goats to the total biomass was somewhat smaller in Eastern than in Western Kajiado (Fig. 6a and b). Similarly to livestock, wildlife biomass was dominated by the large herbivores, including zebra, elephant and giraffe, especially in Eastern Kajiado (Fig. 6a and b). Herbivore biomass was sensitive to rainfall variation and reduced markedly in both regions during the droughts of 1981-1982, 1999-2000, 20052006 and 2008-2009. The greatest reductions in biomass in response to drought occurred in 2008-2009 in Eastern Kajiado and in 1999-2000 and 2005-2006 in Western Kajiado, reflecting strong spatial gradients in the severity of drought impacts. But, biomass increased noticeably following droughts after rainfall, and hence forage conditions, had improved (Fig. 6a and b). The temporal pattern in vegetation production and greenness indexed by the Normalized Difference Vegetation Index (NDVI) largely reflected the rainfall pattern (Fig. S1 a-c).

\section{Trends in Spatial Distributions of Wildlife and Livestock}

The spatial distributions of all the wildlife species, most especially for wildebeest, giraffe impala, contracted dramatically between the 1970s and the 2000s, but the distributions of ostrich (Struthio cumulus massaicus) and zebra expanded in the County. Wildebeest distribution also expanded but only in Western Kajiado (Fig. S2). The ranges for giraffe, impala and gerenuk contracted more severely in Western than in Eastern Kajiado whereas elephant and buffalo became confined mainly to Amboseli Park and nearby pastoral lands in Eastern Kajiado. The density of Grant's gazelle (Nanger granti) reduced between 1977-1980 and 2006-2011 but its spatial distribution changed little. Eland range shifted in 2006-2011 compared to 1977-1980, especially in Eastern Kajiado. In sharp contrast to wildlife species, livestock were densely distributed and their range expanded to cover the entire County between 1977-1980 and 2006-2011 (Fig. S2), implying increasing displacement and competition with wildlife. Nevertheless, the distributions of donkeys, sheep and goats contracted in Eastern Kajiado in the same period. The distributions of nearly all the wildlife and livestock species were most widespread in the 1990s than at any other time over the course of the 1977-2011 monitoring period (Fig. S2).

\section{Relationships Between Trends in Wildlife and Livestock}

The densities of all the wildlife species in the County were significantly negatively correlated with the densities of individual livestock species as well as with the aggregate livestock biomass density with a few exceptions, implying that livestock competed with and or displaced wildlife (Table
S2 in Supplementary materials). The density of gerenuk, a browser, and impala, a mixed grazer-browser, were not significantly correlated with the densities of cattle, sheep and goats, or with the total livestock biomass, suggesting less competition with livestock. The densities of both gazelles were positively correlated with the density of cattle and donkeys and the total livestock biomass but not with the density of sheep and goats, suggesting facilitation by or similar responses to environmental change with cattle and donkeys (Table S2).

\section{Rainfall Influences on Trends}

The aggregate livestock, wildlife and all herbivore biomass were all negatively correlated with the 5-year moving average of the annual rainfall. Even so, rainfall variation explained only 3.1 to $48.6 \%$ of the total variance in biomass (Table S3).

\section{Land Use Change Influences on Trends in Wildlife and Livestock Distribution}

All the wildlife species were far less abundant than livestock in both regions of Kajiado in 1977-1980 and 20062011. Wildlife were generally more abundant in Eastern than Western Kajiado and in 1977-1980 than in 2006-2011 in almost all the land use types in both regions (Fig. S3 and S4). In eastern Kajiado, wildlife was most abundant in the National Parks and pastoral lands and least abundant or absent in cultivated areas (Fig. S3 and S4). A few wildlife species (wildebeest, zebra and both gazelles) were also common in the conservancies. In Western Kajiado, wildlife was most abundant in the pastoral lands but a few species (wildebeest, impala and both gazelles) were common either in the conservancies or on rain fed agricultural lands (Fig. S3 and S4). Livestock were most abundant in the pastoral lands and rain fed agricultural lands in eastern and western Kajiado and in conservancies in Western Kajiado. Livestock numbers declined in 2006-2011 relative to 19771980 in all the land use types with minor exceptions (Fig. S5). Almost all wildlife species were more abundant in 1977-1980 than in 2006-2011 in both regions regardless of settlement density (Fig. S6 and S7). However, some species such as eland and elephant were more abundant in areas of low settlement densities, whereas others such as wildebeest, Thomson's and Grant's gazelles were more uniformly distributed relative to settlement density (Fig. S6 and S7). Livestock density increased with increasing settlement density in both regions of the County (Fig. S8).

\section{DISCUSSION}

\section{Wildlife Declines and Range Contraction}

Moss (2001) documented a decline in the elephant population in the Amboseli ecosystem from 1972 to 1978 followed by a steady increase from 1979 to 2000 . Western \& Nightingale (2003) analyzed wildlife and livestock trends using aerial sample counts covering January 1973 to January 2002. They found that (1) the numbers of cattle, sheep and goats increased significantly between 1973 and 2001. 2) Poachers reduced the Amboseli elephant population from 1000 in 1970 to less than 500 in 1977 but the herd had fully 
recovered by 1998 (Western 2000). 3) Wildlife biomass increased from 1970s following the establishment of the Amboseli National Park and community conservation initiatives. 4) Zebra, elephant and buffalo accounted for most of the increase. They attributed the large increase in elephants to the success of the Amboseli National Park and the participation of Maasai in revenue-sharing schemes and conservation enterprises (Western 1994). 5) Wildebeest numbers fluctuated without an overall trend but rebounded after the droughts of the 1970s and 1980s. 6) Trend patterns for the other common species were mixed. Numbers of Grant's gazelle varied little while those of Thomson's gazelle fluctuated widely. Most browsing species requiring woodlands, including impala, eland and giraffe, decreased due to displacement by cultivation. Hartebeest, a pure grazer, declined steadily. Hartebeest, eland and giraffe also suffered bush meat poaching near the Chyulu Hills. Western et al. (2009) later reported that aggregated wildlife numbers increased, but not significantly, in the Amboseli Park (19692005) and in its adjoining pastoral areas (1973-2005).

Our results show that elephant numbers continued to grow in Eastern Kajiado between 2000 and 2011. Buffalo and zebra also continued to increase until a severe drought drastically reduced their numbers during 2008-2009. Although the other 12 wildlife species also suffered massive mortality during this drought, the numbers of hartebeest, Thomson's gazelle, warthog, waterbuck and oryx had been declining relentlessly before the drought but dropped to alarmingly low levels after the drought. This illustrates how severe droughts can accelerate local population extirpation. In contrast to the earlier studies, our results show that the numbers of all the livestock species declined steadily between 1977 and the 2008-2009 drought, when all livestock species suffered severe mortality. The extreme declines in wildlife and livestock numbers observed for Eastern Kajiado was replicated in Western Kajiado. But wildlife and livestock populations in Western Kajiado were little affected by the 2008-2009 drought unlike their counterparts in Eastern Kajiado.

Populations of wildlife species declined drastically throughout Kajiado but the extent of the decline was greater in the Athi-Kaputiei (Ogutu et al. 2013) than in the greater Amboseli Ecosystem. Only populations of elephant, zebra and ostrich increased between the 1970s and the 2010s. Even so, the populations of zebra and ostrich declined within the greater Amboseli ecosystem. Livestock populations declined likewise but to a greater degree in the Amboseli than in the Athi-Kaputiei ecosystem. Wildlife distribution contracted dramatically in the ecosystem whereas livestock distribution expanded to densely cover the entire ecosystem, implying displacement of wildlife by livestock and greater competition between wildlife and livestock. Only the distribution of two wildlife species (zebra and ostrich) expanded in Kajiado between the 1970s and 2010s. The extreme declines and range contractions are similar to the patterns reported for the adjoining Mara region of Kenya (Ogutu et al. 2009, 2011), Tarangire-Simanjiro of Tanzania (Msoffe et al. 2011) and elsewhere in Kenya (Western et al. 2009) and Africa (Craigie et al. 2010, Scholte 2011). Similarly, dramatic levels of decline were also noted for the Athi-Kaputiei ecosystem (Ogutu et al. 2013).

\section{Rainfall Influences on Wildlife and Livestock Trends}

Western and Nightingale (2003) and Western (2010) documented the following responses of wildlife and livestock population dynamics to droughts in the Amboseli ecosystem during 1973-2002 and 2008-2010. 1) Livestock populations in the Amboseli ecosystem and the adjoining areas have fallen with droughts and risen in rainy periods since the 1960s. Numbers have been falling steadily since the 1990s and fell steeply as a result of the 2008-2009 drought. 2) Cattle numbers fell from a pre-drought level of 200,000 to slightly over 50,000 by late 1970 s and subsequently rebounded to 200,000 for only two brief periods in the 1980s and decreased slightly after the mid1980s. 3) Sheep and goat numbers were less affected by the 1970 s drought and increased steadily from 100,000 predrought to a peak of 170,000 in the $1980 \mathrm{~s}$ and then stabilized. Sheep and goats rose after the 1970s drought and have held steadily since the 1990s. 4) Cattle numbers recover more slowly than sheep and goats after droughts partly due to their longer gestation. The number of sheep and goats increased from approximately 100,000 in 1977 to 130,000 in 2010 , reflecting both their faster recovery from droughts and rising importance to the pastoral economy. 5) Aerial counts carried out by the Amboseli Conservation Program and the Department of Resource Surveys and Remote Sensing (DRSRS) indicated that there has been no significant increase in the number of livestock using the Amboseli Park since 1980. Livestock have not, therefore, been a significant factor in the decline of woodland habitat in Amboseli and the collapse of the wildlife herds. 6) Wildlife numbers fluctuated with rainfall, similarly to livestock, with a lag period of five years.

Our results also show that the combined wildlife biomass was surprisingly negatively correlated with the 5-year moving average of the annual rainfall in Kajiado (Table S3). But it was positively correlated with the combined livestock biomass, contrary to expectation, and suggesting that both wildlife biomass and livestock biomass are similarly affected by the influence of the interannual rainfall variation on vegetation. The negative correlation with rainfall suggests that high rainfall lowers vegetation quality and hence habitat suitability for the herbivores (Edye et al. 1978, Jarrell et al. 1981, Fynn \& O'Connor 2000).

\section{Causes of Wildlife Declines and Range Contraction}

The persistent and marked declines in numbers of certain wild life species despite improvement in conditions following drought losses implicate the involvement of other factors beyond the contribution of rainfall variation. These factors include increasing population pressures, high livestock densities, land development, cultivation, cultural change, spread of firearms and the associated increase in poaching.

\section{Rainfall Variability, Trophic and Anthropogenic Processes}

The 2008-2009 drought was due to a shortage of rain in 2008 (May-Aug) and 2009 (Jan-Apr and Jul-Nov). Wildlife and livestock species suffered heavy losses in the drought, most likely due to restricted access to key resources during the drought (Walker et al. 1987, Owen-Smith 2004). The 
mortalities among wildlife were more than four times recorded levels of at most 20\% since 1967 (Western 2010). Estimated overall losses to the large migratory herbivores were in excess of $75 \%$, with the estimated wildebeest losses exceeding 95\% (Worden et al. 2010b). A leading question then is why this drought was so catastrophic when the rainfall deficit documented for 2008-2009 does not seem exceptionally low compared with previous droughts between 1960 and 2009 during which livestock and wildlife losses were less extreme. The impact of this drought on wildlife was likely amplified by competition with livestock, predation and exclusion of wildlife from their dry season refuges and wet season dispersal areas by agriculture, settlements and blockage or loss of migratory and dispersal corridors.

Competition for water and space between wildlife, livestock, herders and farmers caused by the high density and widening distribution of livestock, settlements and farms (Bourn \& Blench 1999) was likely intensified by the drought. Competition between wildebeest and livestock was noted previously as a problem in Nairobi National Park until all livestock were evicted from the park in May 1967 (Foster $\&$ Kearney 1967). Before then, the Game Department had caused large numerical declines in wildebeest across Kajiado by culling wildebeest from the 1940s to reduce competition with overstocked Maasai cattle that had caused much habitat deterioration (Simon 1962, p. 229). The high livestock density in Kajiado sustaining the competition with wildlife is not new but goes far back in time. For example, Meinertzhagen $(1957$, p. 90) reported counting over 4000 Maasai cattle in an area of about $62 \mathrm{~km}^{2}$ on the AthiKaputiei plains in May 1903. The impact of competition with livestock is likely aggravated by high population pressures, intensification of land use around permanent settlements, habitat desiccation caused by regional warming and loss of woodland cover (Ogutu et al. 2009). Illegal grazing of livestock in the protected parks and reserves during droughts further heighten competition with wildlife (Ntiati 2002). As a result, despite its long history, heavy dependence on livestock has large ecological implications for the future of pastoralism and wildlife conservation in Kajiado and other pastoral lands of Kenya.

Large carnivores kill the weakened wildlife and livestock during droughts, escalating human-wildlife conflicts. This piles additional pressure on herbivores and sharply increases predation of the depleted livestock herds. But the precipitous drop in herbivore numbers also puts the carnivore populations at risk of starvation. Not surprisingly, over 270 livestock were killed by predators over a 2-month period (Sep-Oct) after the 2008-2009 droughts. The consequent sharp rise in predator to prey ratios applied extreme pressure on the remaining few and weakened herbivore populations (KWS/ACC/ACP 2009). Nevertheless, predation alone is unlikely to have played a major role in the long-term herbivore declines because substantial numbers of lions (Panthera leo) and almost certainly of other predators are being killed in the pastoral lands of Amboseli (Frank et al. 2006, Hazzah et al. 2009). Between 2001 and 2006 alone, a minimum of 108 lions were killed in Mbirikani Group Ranch $\left(1200 \mathrm{~km}^{2}\right)$ by poisoning and spearing in spite of a generous carnivore compensation program which pays herders for livestock lost to predators (Frank et al. 2006). The killings are either in retaliation for livestock killed by lions, as a rite of passage (moranism) ritual, or sometimes as a political statement. The rate of killings is likely increasing (Frank et al. 2006). Local youths killed the entire Amboseli National Park lion population between 1991 and 1994 but lions have since re-established themselves in the park by dispersing from the surrounding lands (Frank et al. 2006, Maclennan et al. 2009). Poaching also likely contributed to the herbivore mortalities during the 2008-2009 drought. Poaching of wildlife increases when droughts cause crop failures, livestock mortalities and food shortages (Mduma et al. 1998). Wildlife weakened by food scarcity become more vulnerable to poachers as do those that wander closer to villages inhabited by poachers in search of forage and water during droughts Mduma et al. (1998). Increasing availability of firearms and demand for bush meat further fuel poaching (Western et al. 2009).

Starvation during severe droughts such as 2008-2009 reduces immunity of livestock and wildlife, leading to more deaths from disease (KWS/ACC/ACP 2009). Typically, livestock deplete their pastures earlier than wildlife, resulting in some livestock movements into the parks. When grazing in the parks, livestock contract vector-borne diseases and suffer predation. The frequent droughts linked to high rainfall variability therefore increase vulnerability of the ungulates to diseases and pathogens. Diseases spread faster when wildlife and livestock are forced to concentrate in small areas such as in the park or near a few water points during droughts. For example, in 1996 there was a rinderpest outbreak in Nairobi Park when large numbers of livestock were being illegally grazed there.

The 2008-2009 drought adversely affected the community and its relationship with wildlife in several ways. In general, heavy livestock mortality during droughts causes acute poverty for several years as herds recover. In the 20082009 drought, for instance, minimum livestock losses were reported as $81 \%$ among cattle and $64 \%$ among sheep and goats in Amboseli. Moreover, in Amboseli over 3000 families lost all their livestock (Rombo 843 households, Intonet 249, Kimana/Imbirikani 997, Lengisimu 352, Central 958 households (KWS/ACC/ACP 2009, Seno \& Tome 2013). Such heavy losses pose enormous hardships on the pastoral community. The resulting poverty causes a sharp rise in the use of natural resources, including through charcoal making, bush meat consumption and trophy hunting (KWS/ACC/ACP 2009). The reduced livestock holdings place even greater expectations on wildlife and tourism income and reduce tolerance of livestock losses to wildlife. Other adverse effects on the community arose through wildlife raiding irrigated crops owing to the widespread food scarcity and through increased human-elephant encounters as elephants moved out of the park in search of forage (KWS/ACC/ACP 2009).

By reducing their mobility and flexibility, land use change compromises the ability of wildlife and livestock to cope with mounting challenges presented by climate change and variability, such as frequent severe droughts. Thus, reduced access to concentration areas and water sources in the north and west of the Athi-Kaputiei ecosystem also had a similarly devastating impact on wildebeest population there when the short rains failed in November-December 1960 and 
the long rains in January-May 1961. Their numbers reduced from 8935 to 4830 (Stewart \& Zaphiro 1963), but had recovered to about 7050 by 1964 (Estes \& East 2009, p. 75).

The spread of arable farms in the northern and southern reaches of the migratory range, the irrigation of swamps to the east, subdivision of group ranches and sedentarization of pastoralists has intensified the concentrations of migratory wildebeest herds in Amboseli ecosystem in the dry season (Worden et al. 2010b). Hence the increasing fragmentation of the Amboseli ecosystem raised the vulnerability of wildebeest to the 2008-2009 drought and their ability to recruit replacement numbers from other sub populations once scattered across the ecosystem. An influx of over 2,000 wildebeest and 3,000 zebra from Tsavo and Tanzania into the Amboseli ecosystem relieved the pressure on the large predators in Amboseli caused by the collapse of the herds during the drought. Had the influx not occurred, the wildebeest population of less than 200 surviving the drought in Amboseli could probably have been driven to extinction by predation pressure in the park during the dry season (Worden et al. 2010b). The influx points to the vital importance of the free movement of herds between Amboseli and adjacent ecosystems in sustaining the ecological viability of the Amboseli national park and its recovery from extreme droughts. The link to Tsavo, the largest source of population recharge, is rapidly being severed by small farms springing up along the Loitokitok pipeline. There is an urgent need to secure free passage for this land linkage if the Amboseli herds are to survive future droughts.

The expansion of cultivation poses a major threat to wildlife conservation in Kajiado (Campbell et al. 2000, Kioko et al. 2006b). The dramatic and unregulated land use changes in the group ranches are severely constraining opportunities for seasonal wildlife dispersal outside the protected areas, contributing to population declines both inside and outside the protected areas. Expansion of cultivation and human settlements has accelerated encroachment into the wetlands and displacement of elephant and other wildlife species from the wetlands (Kioko et al. 2006a). Expanding cultivation on riverbanks and swamps is destroying valuable dry-season wildlife habitats. For example, in the area around Amboseli National Park, irrigation-based agriculture confined to a small area within the Namelok fence heavily extracts water, severely limiting its flow beyond the fence for wildlife use hence restricting wildlife range use and distribution. Wildlife restrict their use of water points to the night to avoid conflicts with people and their livestock in the day time (Williams 1998, Kioko et al. 2006b). Competition for the resources at the wetter margins has intensified, both between and among herders and farmers, and with wildlife. This has raised concerns about access to irrigation water and declining water quality due to run-off of fertilizers and pesticides (Campbell et al. 2000).

Woodland cover has declined due to widespread clearing of trees for cultivation, building and fencing materials and for fuel wood (Campbell et al. 2000). Habitat loss due to clearance of woodlands (Campbell et al. 2000) has severely constricted the distribution of such wildlife species as buffalo and elephants. Buffalo now reside mostly within the protected areas. Both species are sensitive to intensification of land use due to their bulk forage requirements and are largely excluded from the Group Ranches because they can injure or kill people and livestock or cause extensive damage to crops and agricultural infrastructure (Worden et al. 2003). Cultivation of the ranches also threatens wildlife through reduced tolerance among people who have shifted to farming (Gadd 2005). The lost tolerance is expressed through increased human wildlife conflicts, as farmers spear, poison, or snare wildlife in retaliation for crop damage or for bush meat (Okello 2005). Increasing human activity within the ranches is also reducing their use by wildlife (Kioko et al. 2006a). The forced concentration of elephants in parts of the region in the dry season due to habitat loss and fragmentation is accentuating habitat deterioration.

The expansion and intensification of crop farming in recent decades (Kioko et al. 2006b) has accentuated wildlife range contraction and food shortages during droughts. The expansion of cultivation competes with wildlife for grazing land and has been associated with wildlife population declines in pastoral lands of the Mara Region of Kenya (Thompson \& Homewood 2002). Human-wildlife conflicts related to crop damage are increasing as more cultivation is undertaken in wildlife dispersal and migratory areas and wetlands are drained for horticulture (Okello 2005, Kioko et al. 2006b). The potential direct costs from crop damage have also increased with the expansion of remunerative horticultural production into areas of wildlife concentration (Campbell et al. 2000). The negative impacts of wildlife on peoples' livelihoods, lowers local support for conservation, raising the risk of extirpation of wildlife populations (Sitati et al. 2005).

The mass mortality in Amboseli in the 2008-2009 drought is evidence of the increasing vulnerability of wildlife to droughts there linked to a long-term decline in grazing range caused by range contraction and deterioration. Evidence for range deterioration is provided by a decline in pasture production based on long-term vegetation monitoring (Western \& Maitumo 2004, Western 2007). The fact that livestock and wildlife populations suffered much less in the adjoining western Kajiado, where they had better access to high habitat diversity, in particular large swamps and abundant woodlands and bushlands than in Amboseli (Russell 2009), supports the contention that the depletion of dry season concentration areas in Amboseli amplified the severity of the 2008-2009 drought. Western \& Maitumo (2004) note that the Amboseli woodlands had largely disappeared by the 1980s due to heavy browsing pressure by elephants. The tall sedges that dominated the swamps and the cynodon grasslands that sustained Amboseli's large concentrations of herbivores during dry seasons and droughts had been all but depleted over the preceding 10 years. Historically, these late season habitats supported upwards of $80 \%$ of the migratory herbivore populations during extreme droughts (KWS/ACC/ACP 2009). The change in habitat and depletion of the swamp sedges in Amboseli are largely attributable to the compression of elephants into the Amboseli following the heavy ivory poaching of the 1970s and the simultaneous exclusion of livestock from the park (KWS/ACC/ACP 2009). The formerly migratory elephant herds concentrated in the basin for protection then increased steadily. Numbers in the park peaked in the early 1990s then began falling as the elephants 
moved out of the park with declining swamp pastures during the dry seasons (KWS/ACC/ACP 2009). Because of the transformation of Amboseli habitats by elephants, elephants now frequently move out of the Park looking for food and often raid small farms, increasing conflict with people. But a recently created consolation scheme has reduced spearing of problem elephants, which is distinct from the recent surge in killings of elephants for ivory (KWS/ACC/ACP 2009).

\section{Land Subdivision, Sedentarization of Settlements and Land Fragmentation}

Land use change has had a major impact upon wildlife declines in Kajiado based on land-use specific distinctions in population declines. First, disaggregation of bomas following privatization of land tenure and land subdivision has led to an increase in boma density (Grandin 1991, Kimani \& Pickard 1998) and reduced wildlife density in the group ranches (Mworia et al. 2008). Mworia et al. (2008) also reported that cattle and boma densities strongly influence wildlife distribution in the Amboseli group ranches. Our results also show that large areas of Kajiado are now under cultivation or are occupied by dense settlements and that wildlife ranges have drastically declined and their densities are either zero or very low in cultivated and densely settled areas. This reaffirms the suggestion of Western et al. (2009) and Groom \& Western (2013) that the more uniformly spread and permanent settlement patterns resulting from subdivision have left few undisturbed areas for wildlife and contributed to the wildlife declines.

Second, sedentarization causes population declines through direct displacement of wildlife and suppression of grassland productivity following a switch from seasonal to permanent grazing (Western et al. 2009, Kioko et al. 2006a, Western et al. 2009, Kioko \& Okello 2010). The pure browsers (giraffe, gerenuk) and mixed feeders (impala) have likely benefited from the spread of bushlands associated with sedentarization and intensification of land use and the loss of elephants and rhinos (Diceros bicornis) as indicated by their relatively high densities (Worden et al. 2003). Amboseli gerenuk increased in Kajiado not only due to bush encroachment but also because they require no water whatever (Simon 1962, p. 234). Sedentarization has reduced mobility, productivity, disease avoidance and drought resilience of livestock and wildlife. Continuous grazing around permanent settlements not only lowers plant productivity but also favors the spread of unpalatable herbs and shrubs. Areas remote from permanent settlements lose the patchiness and diversity of habitats resulting from mobile corrals and the nutrient hotspots they create in these savannas (Western et al. 2009). Sedentarization also threatens the diversity and abundance of wildlife as woodlands are depleted close to settlements for charcoal, fuel wood, building and fencing materials (Western \& Dunne 1979, Western \& Nightingale 2003). The growing demand for title deeds among pastoralists to counter land losses and the resulting sedentarization is therefore likely to remain one of the biggest and enduring threats to wildlife in the pastoral lands of East Africa (Western et al. 2009).

Third, land fragmentation through uncontrolled expansion of fences, roads, cultivation and settlements is adversely affecting wildlife and livestock populations. The cultivation and fencing of the Amboseli swamps has resulted in the local extirpations of populations of several species with strong dependence on water or areas near water, including buffalo and hippo (Hippotamus amphibius) and the near collapse of those of elephant, zebra and wildebeest (Worden et al. 2003). Fragmentation has disrupted established migration pathways for wildlife and livestock, access to drought reserves and flexibility in avoiding disease outbreaks. For example, the seasonal movements of elephants between the group ranches and Amboseli National Parks in search of water and forage is getting increasingly restricted by electric fences, loss of migratory corridors, human settlements, actual presence and human activities (Kioko et al. 2006a). The enclosure of water holes and pastures in fences (Kioko et al. 2006b) further denies wildlife access to water and grazing (Campbell et al. 2000).

\section{Steps Being Taken to Address the Declines and Suggested Interventions}

The extreme loss of wildlife and their habitats calls for urgent steps to rehabilitate the depleted wildlife and habitat richness of the ecosystems and restore their ecological resilience to drought. Effective measures should consider both wildlife and livestock, enhance tourism potential, returns from wildlife conservation efforts and pastoralism and hence pastoral livelihoods. The measures need to address, at the very least, the following six conservation and development priorities. (1) Maintain high wildlife abundance, diversity and dynamism, preserve mobility, flexibility and habitat heterogeneity fundamental to resilience and stability in the arid and semi-arid pastoral lands. (2) Support habitat heterogeneity by protecting critical drought refuges (e.g. swamps, riverine and other woodlands) and maintain a proper balance between key species such as elephants and people. (3) Urgently regulate and plan the expansion of permanent settlements, infrastructure, fences and cultivation in the pastoral lands. (4) Designate zones for wildlife and livestock grazing and settlements, set and effectively enforce rules and regulations governing land use, land sales, land leases to farmers, share cropping and development on critical wildlife migration routes to stem the destruction of wildlife and livestock and their habitats. (5) Restock locally endangered wildlife species, including wildebeest and buffalo from outside the ecosystem. Livestock stocking levels should be concurrently reduced and regulated. (6) The pastoral lands and the interventions should be monitored to identify the factors which contribute to the success or failure of specific interventions, strategies and practices.

Despite the myriad challenges, there is a growing interest in conservation as evidenced by the recent formation of conservancies and sanctuaries involving contractual partnerships between private land owners and private investors in tourism enterprises. For example, the Kimana Group Ranch has created a wildlife sanctuary that generates revenues from wildlife viewing. Group ranch members who see its potential to generate significant income are protecting this land unit from subdivision and encouraging the ranch to continue to operate as a single unit, even though informal subdivision around wetlands continues (Campbell et al. 2000). Maintaining the linkages between all the conservancies, 
National Parks and pastoral lands will allow continued wildlife movements between them. The conservancies are enabling the development of new economic incentives that support both conservation and the pastoral communities. For example, new ecotourism investments in the pastoral ranches are providing income, employment, trade and business opportunities and improving infrastructure and fostering more positive local attitudes towards wildlife (Ogutu 2002). By generating economic returns to the local communities and offsetting the costs of wildlife conservation on the pastoral lands, the conservancies help reduce the hostility of land users towards wildlife (Campbell 1999). The benefits for wildlife and livelihoods are stimulating the formation of more conservancies. The conservancies are therefore fast becoming an important focus of contemporary wildlife management policy and practice. Many area residents have a positive attitude towards biodiversity conservation due to the economic gains already received or expected from the conservation initiatives. If the benefits are shared equitably, the potential for conservation will remain high. However, some community members perceive conservation as only benefiting a few. Were this to become a widespread and enduring attitude, the pressure for subdivision will continue to mount. Significant investments in community capacity building for better natural resource and financial management are needed to ensure the viability of these conservation initiatives to maintain a wildlife sector that is vibrant and not vulnerable to changes in social processes and alterations in the resource base. Wildlife managers and conservationists are exploring and promoting various incentives that increase economic returns from wildlife and reduce land subdivision and expansion of cultivation.

Besides the business enterprises, conservation land leases, easements, and land trusts that have proved successful elsewhere are being explored as options to transform conservation into economic and social advantage and reduce the environmental threats while ensuring the continued availability and access to the critical portions of the pastoral lands. The emerging wildlife enterprises do, however, call for user rights and spreading the cost burden (Emerton 2001). Even so, the policy, legal and institutional instruments crucial to the formation and proper functioning of the enterprises on the private lands are still in their infancy. The enactment by parliament of the Kenya Wildlife Act 2013, which addresses many deficiencies in the existing wildlife legislation, has the potential to enhance wildlife conservation in both protected and pastoral lands of Kenya, if well implemented. The complexity of the manifold driving forces of land use changes, their convergence and interactions calls for multi-sectorial policies and planning procedures that allow for the considerable uncertainties, contingencies and constraints associated with achieving specific future outcomes by seeking to maintain flexibility in future options (Campbell et al. 2000). The past policies that invested KWS with ownership and user rights and full control over and management rights to almost all wildlife resources in Kenyan state, while denying compensation to land owners for the costs of raising wildlife have undermined rather than promoted adoption of truly devolved and collaborative wildlife management in Kenya and urgently require re-thinking. Since custodianship follows from ownership, there is a pressing need for a policy framework and legislation that genuinely decentralizes and devolves wildlife conservation and management rights, roles and responsibilities on the pastoral lands. The capacity of governmental institutions and organized groups to collaboratively manage wildlife resources should also be strengthened by far-sighted policies and legislations.

The extreme wildlife declines and the continuing and intensifying competition and conflict between people and wildlife in the rangelands despite years of government policies, intensive efforts at improving community involvement in wildlife management and considerable economic incentives for the communities to support wildlife means that these efforts have failed. Reducing these conflicts requires re-thinking, recasting and implementing novel policies, legislations, management institutions and strategies. These should promote sustainable human livelihood systems alongside vibrant wildlife populations, be broadly acceptable and effective. Rain fed agriculture is unsustainable in the long-term in large parts of Kajiado and other arid and semiarid pastoral lands of Kenya. Hence, encouraging pastoralism, discouraging short-lived agricultural conversion in the wildlife ranges and investing in compatible land uses such as wildlife conservation is more likely to avert shortterm conflict and protect wildlife and pastoral livelihoods in the long term than persuading farmers to be tolerant to wildlife after land has been cultivated (Gadd 2005). Land owners should be dissuaded from investing earnings from conservation in paying for land subdivision, cultivation and purchasing more livestock, all of which undermine conservation goals (Gadd 2005). This is more likely to succeed if the high costs of having wildlife on their lands are reduced. Schemes have been established to make consolation payments for livestock depredation as part of wider efforts to reduce human-wildlife conflicts (Ogutu et al. 2013, Maclennan et al. 2009). But the regional scope and resources available for these schemes are very limited. The consolation funds are also not sustainable in the long-term in their current forms. People living in the dispersal areas should be compensated not only for wildlife-related injuries and fatalities but also for property damage, including livestock depredation and crop raiding, to minimize retributive killing of wildlife. But compensation would become irrelevant if communities were granted wildlife ownership and custodianship.

Finally, the future of wildlife populations on the pastoral lands of Kenya critically depends on the good will and support of the local communities who continue to tolerate wildlife on their lands despite the huge costs they incur. They are being encouraged and supported to set up wildlife conservancies to promote conservation, pastoralism and livelihoods by the Kenya Wildlife Service, various local, national, regional and international NGOs. Policy-makers need to conceptualize pastoral ecosystem management in terms of coupled ecological, social, economic and political processes (Campbell et al. 2000). In particular, they should recognize how complex and dynamic interactions between these processes drive changes in land use and cover, the distribution and composition of wildlife and livestock and their habitats, access to water, water quantity and quality and the principal livelihood systems dependent on the land and water resources. 


\section{CONFLICT OF INTEREST}

The authors confirm that this article content has no conflicts of interest.

\section{ACKNOWLEDGEMENTS}

We thank the Kenya Wildlife Service (KWS) and the Department of Resource Surveys and Remote Sensing of Kenya (DRSRS) for permission to use the animal counts. The Kenya Meteorological Department provided rainfall and temperature data. We are grateful to Dr. Richard Fynn, the editor and an anonymous reviewer for suggestions that helped improve an earlier version of this paper. The National Science Foundation of America (NSF) supported data processing, analysis and writing through Grants (No.s: BCS 0709671 and DEB-0342820) to the International Livestock Research Institute. ESPA supported MYS and SCK through the project: Biodiversity, Ecosystem Services, Social Sustainability and Tipping Points in African Drylands (BEST).

\section{REFERENCES}

Altmann, J, Alberts, SC, Altmann, SA \& Roy, SB (200) Dramatic change in local climate patterns in the Amboseli basin, Kenya. African Journal of Ecology, 40, 248-51.

Andere, DK (1981) Wildebeest Connochaetes taurinus (Burchell) and its food supply in Amboseli Basin. African Journal of Ecology, 19, 239-50.

Barnett, R (1997) Food for thought: the utilization of wild meat in eastern and southern Africa, TRAFFIC, East/Southern Africa, Nairobi, Kenya.

Barnett, R (2000) Food for thought: the utilization of wild meat in Eastern and Southern Africa, TRAFFIC, East/Southern Africa, Nairobi, Kenya, pp. 212.

Berger, DJ (1993) Wildlife extension: participatory conservation by the Massai of Kenya, ACTS Press, African Centre for Technology Studies.

Bhola, N, Ogutu, JO, Redi, RS, Olff, H, Piepho, HP \& Hobbs, NT (2012) Comparative changes in density and demography of large herbivores in Maasai Mara Reserve and the adjacent Koyiaki Pastoral Ranch, Kenya. Biodiversity Conservation, 21, 1509-30.

Bhola, N, Ogutu, JO, Said, MY \& Olff, H (2012) Herbivore hotspots in the Mara region of Kenya in relation to land use. Journal of Animal Ecology, 81, 1268-87.

Boone, RB \& Hobbs, NT (2004) Lines around fragments: effects of fencing on large herbivores. African Journal of Range and Forage Science, 21, 147-58.

Boone, RB, Burn Silver, SB, Thornton, PK, Worden, JS \& Galvin, KA (2005) Quantifying declines in livestock due to land subdivision. Rangeland Ecology and Management, 58, 523-32.

Bourn, D \& Blench R (1999) Can livestock and wildlife co-exist? An interdisciplinary approach. Livestock, wildlife and people in the semi-arid rangeland of Eastern Africa, Overseas Development Institute (ODI).

Boutton, TW, Tieszen, LL \& Imbamba SK (1988) Biomass dynamics of grassland vegetation in Kenya. African Journal of Ecology, 26, 89101

Brashares, JS, Arcese, P, Sam, MK, Coppolillo, PB, Sinclair, ARE \& Balmford, A (2004) Bushmeat hunting, wildlife declines, and fish supply in West Africa. Science, 306, 1180-83.

Campbell, DJ (1993) Land as ours, land as mine: Economic, political and ecological marginalization in Kajiado District 1993, In: Spear T \& Waller R (Eds), Being Maasai, James Currey, London.

Campbell, DJ (1999) Response to drought among farmers and herders in southern Kajiado District, Kenya: a comparison of 1972-1976 and 1994-1995. Human Ecology, 27, 377-415.

Campbell, DJ, Gichohi, H, Mwangi A \& Chege, L (2000) Land use conflicts in SE Kajiado District, Kenya. Land Use Policy, 17: 338-48.
Campbell, DJ, Lusch, DP, Smucker, T \& Wangui, EE (2003). Land Use Change Patterns and Root Causes in the Loitokitok Area, Kajiado District, Kenya, LUCID Report \#19, International Livestock Research Institute, Nairobi, Kenya.

Caro, T \& Scholte, P (2007) When protection falters. African Journal of Ecology, 45, 233-35.

Caro, $T$ (2008) Decline of large mammals in the Katavi-Rukwa ecosystem of western Tanzania. African Zoology, 43, 99-116.

Chambers, R (1997) Whose reality counts? Putting the first last. Intermediate Technology Publications, London.

Coe, MJ, Cumming, DH \& Phillipson, J (1976) Biomass and production of large African herbivores in relation to rainfall and primary production. Oecologia, 22, 341-54.

Craigie, ID, Baillie, JEM, Balmford, A, Carbone, C, Collen, B, Green, RE \& Hutton, JM (2010) Large mammal population declines in Africa protected areas. Biological Conservation, 143, 2221-8.

de Boor, C (2001) A practical guide to splines, revised ed, Springer, New York.

Deshmukh, IK (1984) A common relationship between precipitation and grassland peak biomass for east and southern Africa. African Journal of Ecology, 22, 181-86.

Edye, LA, Williams, WT \& Winter, WH (1978) Seasonal relations between animal gain, pasture production and stocking rate on two tropical grass-legume pastures. Crop and Pasture Science, 29, 103-13.

East, R (1984) Rainfall, soil nutrient status and biomass of large African savanna mammals. African Journal of Ecology, 22, 245-70.

Ecosystems Ltd (1982) Report on Amboseli/Lower rift regional study prepared for the wildlife planning unit, Ministry of Tourism and Wildlife, Republic of Kenya, REF: PR/60.

Eilers, PHC \& Marx, BD (1996) Flexible smoothing with B-splines and penalties. Statistical Science, 11, 89-121.

Emerton, L (2001) The nature of benefits \& the benefits of nature: why wildlife conservation has not economically benefited communities in Africa? In: Hulme, D \& Murphree, M (Eds), African wildlife and livelihoods: the promise and performance of community conservation, pp. 208-26, James Currey Ltd, Oxford, UK.

ESRI (2011) ArcGIS Desktop: Release 10. Redlands, CA: Environmental Systems Research Institute.

Estes, RD \& East, R (2009) Status of the wildebeest (Connochaetes taurinus) in the wild 1967-2005 working paper \# 37 July 2009. WCS Working Papers: ISSN 1530-4426. Online posting: ISSN 1534-7389.

Fischer, F \& Linsenmair, KE (2007). Changing social organization in an ungulate population subject to poaching and predation- the kob antelope (Kobus kob kob) in the Comoe National Park, Cote d'Ivore. African Journal of Ecology 45, 285-92.

Foster, JB \& Kearney, D (1967) Nairobi National Park game census. East African Wildlife Journal, 5, 112-20.

Frank, L, Maclennan, SD, Hazzah, L, Bonham, R \& Hill, T (2006) Lion killing in the Amboseli-Tsavo ecosystem, 2001-2006, and its implications for Kenya's lion population. Nairobi: Kilimanjaro Lion Conservation Project and the Predator Compensation Fund and Maasailand Preservation Trust. Available from: http://www.johnbanovich.com/clients/banovichpride/PDF/LionKill ing506.pdf

Fritz, H, Duncan, P (1994) On the carrying capacity for large ungulates of African savanna ecosystems. Proceedings of the Royal Society of London Series B: Biological Sciences, 256, 77-82.

Fynn, RWS \& O'Connor TG (2000) Effect of stocking rate and rainfall on rangeland dynamics and cattle performance in a semi-arid savanna, South Africa. Journal of Applied Ecology, 37, 491-507.

Fynn, RWS \& Bonyongo, MC (2010) Functional conservation areas and the future of Africa's wildlife. African Journal of Ecology, 49, 175-88.

Gadd, M (2005) Conservation outside of parks: attitudes of local people in Laikipia, Kenya. Environmental Conservation, 32, 50-63.

Gichohi, H (2011) In their own words. Africa Geographic, 19(1), 43-5.

Gichuki, NN, Oyieke, HA \& Ndiritu, GG (2001) Assessment and monitoring of wetlands for conservation and development in dry lands: A case study of Kajiado District, Kenya, pp. 97-111, In: Finlayson, CM, Davidson, NC \& Stevenson, NJ (Eds), Wetland inventory, assessment and monitoring: practical techniques and identification of major issues: Proceedings of Workshop $42^{\text {nd }}$ International Conference on Wetlands and Development, Dakar, Senegal, 8-14 November 1998. 
Grandin, BE (1991) The Maasai: socio-historical context and Group Ranches. In Maasai herding: An analysis of the livestock production system of Maasai pastoralists in eastern Kajiado District, Kenya. In: Bekure, S, de Leeuw PN, Grandin BE \& Neate PJH (Eds), ILCA Systems Study 4, pp. 21-39, International Livestock Center for Africa, Addis Ababa, Ethiopia.

Grieves-Cook, J (2011) In their own words. Africa Geographic, 19, 43-5.

Groom, RJ \& Western, D (2013) Impact of land subdivision and sedentarization on wildlife in Kenya's southern rangelands. Rangeland Ecology and Management, 66, 1-9.

Hazzah, L, Borgerhoff, MM \& Frank, L (2009) Lions and warriors: social factors underlying declining African lion populations and the effect of incentive-based management in Kenya. Biological Conservation, 142, 2428-37.

Heath, B (2011) In: Their Own Words. Africa Geographic, 19(1), 43-5.

Homewood, K, Lambin, EF, Coast, E, Kariuki, A, Kikula, I, Kivelia, J, Said, MY, Serneels, S \& Thompson, M (2001) Long-term changes in Mara-Serengeti wildlife and land cover: pastoralists, population or policies? Proceedings of the National Academy of Science, 98, $12544-9$.

Homewood, K (2009) Policy and practice in Kenyan rangelands: impacts on livelihoods and wildlife. In: Homewood, K, Kristjanson, P\& Trench, PC (Eds), Staying Maasai? Livelihoods, conservation and development in East African rangelands, pp. 335-67, Springer, New York.

Homewood, K, Kristjanson, P, Trench, PC (2009) Changing land use, livelihoods and wildlife conservation in Maasailand. In: Homewood, K, Kristjanson, P \& Trench, PC (Eds.), Staying Maasai? Livelihoods, conservation and development in East African rangelands, pp. 369-408, Springer, New York.

Howe, M, Okello, MM \& Davis, JM (2013) Interspecific variation in the distribution of ungulates relative to human infrastructure surrounding Amboseli National Park. African Zoology, 48, 159-66.

Jarrell, WM \& Beverly, RB (1981) The dilution effect in plant nutrition studies. Advances in Agronomy, 34, 197-224.

Jolly, GM (1969) Sampling methods for aerial censuses of wildlife populations. East African Agricultural and Forestry Journal, 34, 46-9.

Jones, B (2001) The evolution of a community-based approach to wildlife management at Kunene, Namibia. In: Hulme D \& Murphree M (Eds), African wildlife and livelihoods: the promise and performance of community conservation, James Currey, Oxford.

Juma, C (1989). Environmental and economic policy in Kenya. In: Institutional innovations in land use management in Kenya, African Centre for Technology Studies Press, Nairobi, Kenya.

Kabiri, N (2010) The political economy of wildlife conservation and decline in Kenya. Journal of Environment and Development, 19, 424-45.

Kahumbu, P, Byamukama, L, Mbuthia, J \& Ofir, D (2014). Scoping study on the prosecution of wildlife related crimes in Kenyan courts: January 2008 to June 2013. Wildlifedirect, Nairobi, Kenya. Available online at http://baraza.wildlifedirect.org/files/2014/01/WILDLIFEDIRECT-court-study-26.1.14.pdf

Kaka, A (2011) In Their Own Words. Africa Geographic, 19(1), 43-5.

Kassa, B, Libois, R, Sinsin, B (2008) Diet and food preference of the waterbuck (Kobus ellipsiprymnus defassa) in the Pendjari National Park, Benin. African Journal of Ecology, 46, 303-10.

Kimani, K \& Pickard, J (1998) Recent trends and implications of group ranch sub-division and fragmentation in Kajiado district of Kenya. Geographical Journal, 164, 202-13.

King, A (2000) Managing without institutions: the role of communication networks in governing resource access and control. Cuvillier Verlag, Goettingen.

King, A (2011) No reason to conserve: exploring the drivers and performance of wildlife conservation in Kenya, pp. 78-85. In: Abensperg-Traun, M, Roe D, O'Criodain, C (Eds), CITES and CBNRM proceedings of an international symposium on the relevance of CBNRM to the conservation and sustainable use of CITES-listed species in exporting countries.

Kioko, J, Okello, MM \& Muruthi, P (2006a) Elephant numbers and distribution in the Tsavo-Amboseli ecosystem, south-western Kenya. Pachyderm, 40, 61-8.

Kioko J, Okello, MM \& Muruthi, P (2006b) Human-elephant conflict outlook in the Tsavo-Amboseli ecosystem, Kenya. Pachyderm, 41, 53-60.
Kioko, J, Muruthi, P, Omondi, P \& Chiyo, PI (2008) The performance of electric fences as elephant barriers in Amboseli, Kenya. South African Journal of Wildlife Research, 38, 52-8.

Kioko, J \& Okello, MM (2010) Land use cover and environmental changes in a semi-arid rangeland, Southern Kenya. Journal of Biogeography and Rangeland Planning, 3, 322-26.

KWS/ACC/ACP (2009) The impact of the 2009 drought on wildlife, livestock and tourism in the Amboseli ecosystem: recommendations for prompt action and ecosystem restoration. Proceedings of the Amboseli Ecosystem workshop, Serena Lodge, Amboseli, 9th December.

Lamprey, RH \& Reid, RS (2004) Expansion of human settlement in Kenya's Maasai Mara: what future for pastoralism and wildlife? Journal of Biogeography, 31, 997-1032.

Maclennan, SD, Groom, RJ, Macdonald, DW \& Frank, LG (2009). Evaluation of a compensation scheme to bring about pastoralist tolerance of lions. Biological Conservation, 142, 2419-27.

Mburu, J (2004) Wildlife conservation and management in Kenya: towards a co-management approach. Fondazione Eni Enrico Mattei, Working Papers, Series 47.

Mduma, SAR, Sinclair, ARE, Hilborn, R (1999) Food regulates the Serengeti wildebeest: a 40-year record. Journal of Animal Ecology, 68, 1101-22.

Mduma, SAR, Hilborn, R \& Sinclair, ARE (1998) Limits to exploitation of Serengeti wildebeest and implications for its management. In: Newbury, DM, Prins, HHT \& Brown, N (Eds.), Dynamics of tropical communities, pp. 243-65. Blackwell Science, Oxford.

Meguro, T \& Inoue, M (2011) Conservation goals and betrayed by the use of wildlife benefits in community-based conservation: the case of Kimana sanctuary in southern Kenya. Human Dimensions Wildlife, $16,30-44$.

Meinertzhagen, R (1957) Kenya Diary 1902-1906. Oliver and Boyd, Edinbugh and London.

Moss, CJ (2001) The demography of an African elephant (Loxodonta africana) population in Amboseli, Kenya. Journal of Zoology, 255, $145-56$.

Msoffe, F, Kifugo, SC, Said, MY, Ole Neselle, M, Van Gardingen, P, Reid, RS, Ogutu, JO, Herero, M \& de Leeuw, J (2011) Drivers and impacts of land-use change in the Maasai Steppe of northern Tanzania: an ecological, social and political analysis. Journal of Land Use Science, 6, 261-81.

Mworia, JK, Kinyamario, JI \& Githaiga, JM (2008) Influence of cultivation, settlements and water sources on wild life distribution and habitat selection in south-east Kajiado, Kenya. Environmental Conservation, 35, 117-24.

Nelson, F (2010) Community Rights, Conservation \& Contested Land: the politics of natural resource governance in Africa. Earthscan, London.

Nicholson, SE \& Kim J (1997) The relationship of the El Niño-southern oscillation to African rainfall. International Journal of Climate, 17, 117-35.

Noe, C (2003) The dynamics of land use changes and their impacts on the wildlife corridor between Mt. Kilimanjaro and Amboseli National Park, Tanzania. LUCID Project, International Livestock Research Institute.

Norton-Griffiths, M (1978) Counting animals, Handbook No. 1. African Wildlife Leadership Foundation, Nairobi, Kenya.

Norton-Griffiths, M (1996) Property rights and the marginal wildebeest: an economic analysis of wildebeest conservation options in Kenya. Biodiversity Conservation, 5, 1557-77.

Norton-Griffiths, M (1998) The economics of wildlife conservation policy in Kenya. In: Milner-Gulland, EJ, Mace, R (Eds), Conservation of Biological Resources, pp. 279-93. Blackwell, Oxford.

Norton-Griffiths, M (2000) Wildlife losses in Kenya: an analysis of conservation policy. Natural Resources Modeling, 13, 1-16.

Norton-Griffiths, M \& Butt, B (2003) Undertakers or midwives? The economics of land use changes in Lotokitok Division of Kajiado District, Kenya. LUCID working paper, series \#34.

Norton-Griffiths, M (2007) How many wildebeests do you need? World Economics, 8, pp. 41-64.

Norton-Griffiths, M \& Said, MY (2010) The future for wildlife on Kenya's rangelands: an economic perspective. In: du Toit, JT, Kock, R \& Deutsch, JC (Eds), Wild rangelands: conserving wildlife while maintaining livestock in semi-arid ecosystems, John Wiley \& Sons, Ltd, Chichester, UK. 
Ntiati, P (2002) Group ranches subdivision study in Loitokitok division of Kajiado District, Kenya. Land Use Change Impacts and Dynamics (LUCID) Working Paper \#7, International Livestock Research Institute, Nairobi, Kenya.

Ogallo, LJ (1982) Quasi-periodic patterns in the East African rainfall records. Kenya Journal of Science and Technology (A), 3, 43-54.

Ogolla, BD \& Mugabe, J (1996) Land tenure systems and natural resource management. In land we trust: environment, private property and constitutional change. Initiatives Publishers, Nairobi, Kenya.

Ogutu, JO \& Owen-Smith, N (2003) ENSO, rainfall and temperature influences on extreme population declines among African savanna ungulates. Ecol Letters, 6, 412-29.

Ogutu, JO, Piepho, HP, Dublin, HT, Bhola, N \& Reid, RS (2008) El NiñoSouthern Oscillation, rainfall, temperature and normalized difference vegetation index fluctuations in the Mara-Serengeti ecosystem. African Journal of Ecology, 46,132-43.

Ogutu, JO, Piepho, HP, Dublin, HT, Bhola, N\& Reid, RS (2009) Dynamics of Mara-Serengeti ungulates in relation to land use changes. Journal of Zoology, 278, 1-14.

Ogutu, JO, Owen-Smith, N, Piepho, HP \& Said, MY (2011) Continuing wildlife population declines and range contraction in the Mara region of Kenya during 1977-2009. Journal of Zoololgy, 285, 99109.

Ogutu, JO, Owen-Smith N, Piepho, HP, Kuloba B, \& Endebe, J (2012) Dynamics of ungulates in relation to climatic and land use changes in an insularized African savanna ecosystem. Biodiversity Conservation, 21, 1033-53.

Ogutu, JO, Owen-Smith, N, Piepho, HP, Said, MY, Kifugo, S \& Reid, RS (2013) Changing wildlife populations in Nairobi National Park and adjoining Athi-Kaputiei Plains: collapse of the migratory wildebeest. The Open Conservation Biology Journal, 7, 11-26.

Ogutu, ZA (2002) The impact of ecotourism on livelihood and natural resource management in Eselenkei, Amboseli ecosystem, Kenya. Land Degradation and Development, 13, 251-56.

Okello MM \& Kiringe JW (2004) Threats to biodiversity and their implications in protected and adjacent dispersal areas of Kenya. Journal of Sustainable Tourism, 12, 55-69.

Okello, MM (2005) Land use changes and human-wildlife conflicts in the Amboseli Area, Kenya. Human Dimensions of Wildlife, 10, 19-28.

Okello, MM, Wishitemi, BE \& Lagat, B (2005) Tourism potential and achievement of protected areas in Kenya: criteria and prioritization. Tourism Analysis, 10, 151-64.

Okello, MM \& D’Amour, DE (2008) Agricultural expansion within Kimana electric fences and implications for natural resource conservation around Amboseli National Park, Kenya. Journal of Arid Environments, 72, 2179-92.

Okello, MM, Ole Seno, SK \& Nthiga, RW (2009) Reconciling people's livelihoods and environmental conservation in the rural landscapes in Kenya: opportunities and challenges in the Amboseli landscapes. Natural Resources Forum, 33: 123-33.

Okello, MM \& Kioko, JM (2010) Contraction of wildlife dispersal area in Olgulului- Ololorashi Group Ranch around Amboseli National Park, Kenya. The Open Conservation Biology Journal, 4, 34-45.

Okello, MM \& Kioko, JM (2011) A field study in the status and threats of cultivation in Kimana and Ilchalai swamps in Amboseli dispersal area, Kenya. Natural Resources, 2, 197-211.

Ole Katampoi, K, Genga, G, Mwangi, M, Kipkan, J, Ole Seitah, J, Van Klinken MK \& Mwangi, MS (1990) Kajiado District atlas, Kajiado, Kenya, p. 123, ASAL Programme Kajiado and the Ministry of Reclamation and Development of Arid, Semi-Arid Areas and Wastelands.

Ottichilo, WK, de Leeuw, J, Skidmore, AK, Prins, HHT \& Said, MY (2000) Population trends of large non-migratory wild herbivores and livestock in the Maasai Mara ecosystem, Kenya, between 1977 and 1997. African Journal of Ecology, 38, 202-16.

Ottichilo, WK \& Khaemba, WM (2001) Validation of observer and aircraft calibration for aerial surveys of animals. African Journal of Ecology, 39, 45-50.

Ottichilo, WK, de Leeuw, J \& Prins, HHT (2001) Population trends of resident wildebeest (Connochaetes taurinus hecki) and factors influencing them in the Masai Mara ecosystem, Kenya. Biological Conservation, 97, 271-82.

Owen-Smith, N (2004) Functional heterogeneity in resources within landscapes and herbivore population dynamics. Landscape Ecology, 19, 761-71.
Parker, I, Smith, K (2001) Early History. In: Parker I and Bleazard S (Eds). An impossible dream. Moray, UK: Librario Publishing Ltd. pp. 512.

Pennycuick, CJ \& Western, D (1972) An investigation of some sources of bias in aerial transect sampling of large mammal populations. East African Wildlife Journal, 10, 175-91.

Pratt, DJ \& Gwynne, MD (1977) Rangeland management and ecology in East Africa. Hodder and Stoughton, London.

Reid, RS, Gichohi, H, Said, MY, Nkedianye, D, Ogutu, JO, Kshatriya M, Kristjanson, P, Kifugo, SK, Agatsiva, JL, Andanje, SA \& Bagine, R (2008) Fragmentation of a peri-urban savanna, Athi-Kaputiei Plains, Kenya. In: Galvin KA, Reid RS, Behnke RH \& Hobbs NT (Eds), Fragmentation in arid and semi-arid landscapes: consequences for humans and natural systems. Dordrecht, Springer, pp. 195-224.

Ruppert, D, Wand, MP \& Carroll, RJ (2003) Semiparametric regression. Cambridge University Press, Cambridge.

Russell, S (2009) Report on the impact of the 2009 drought on the South Rift Valley ecosystem and comparison to the Amboseli Ecosystem. Unpublished Report, African Conservation Center, Nairobi.

Said, MY, Ogutu, JO, Kifugo, SC, Nkedianye, D, Reid, RS, Gichohi, H, Serneels, S, de Leeuw, J \& Lambin, EH (2014) Land fragmentation in the Athi-Kaputiei plains of Kenya through fencing: implications for wildlife conservation and pastoralism. Submitted.

Saji, NS, Goswami, BN, Vinayachandran, PN \& Yamagata, T (1999) A dipole mode in the tropical Indian Ocean. Nature, 401, 360-63.

SAS Institute (2013). SAS system for windows, Version 9.3. SAS Institute Inc. Carey, NC, USA.

Scholte, P, Adam, S \& Serge, BK (2001) Population trends of antelopes in Waza National Park (Cameron) from 1960 to 2001: the interacting effects of rainfall, flooding and human interventions. African Journal of Ecology, 45, 431-39.

Scholte, P (2011) Towards understanding large mammal population declines in Africa's protected areas: a west-central African perspective. Tropical Conservation Science, 1, 1-11.

Sen, A (1981) Poverty and famines: an essay on entitlement and deprivation. Oxford University Press, Oxford, UK.

Seno, SK \& Shaw, WW (2002) Land tenure policies, Maasai traditions, and wildlife conservation in Kenya. Society and Natural Resources, 15 , 79-88.

Seno, SK \& Tome S (2013) Socioeconomic and ecological variability of pastoralism in Loitokitok District, Southern Kenya. Nomadic Peoples, 17, 66-86.

Serneels, S \& Lambin, EF (2001) Impact of land use changes on the wildebeest migration in the northern part of the Serengeti-Mara ecosystem. Journal of Biogeography, 28, 391-407.

Shikwati, J (2003) How to protect people and wildlife in Kenya. PERC Reports, vol. 21, no. 1. Montana, USA.

Simon, N (1962) Between the sunlight and the thunder: The wildlife of Kenya. Collins, London.

Sindiga, I (1995) Wildlife-based tourism in Kenya. Journal of Tourism Studies, 6, 45-55.

Sindiga, I (1999) Tourism and African development: change and challenge of tourism in Kenya. African Studies Centre Research Series.

Sitati, NW, Walpole, MJ \& Leader-Williams N (2005) Factors affecting susceptibility of farms to crop raiding by African elephants: using a predictive model to mitigate conflict. Journal of Applied Ecology, $42,1175-82$.

Stoner, C, Caro, T, Mduma, SAR, Mlingwa, C, Sabuni, G, Borner, M \& Schelten, C (2006) Changes in large herbivore populations across large areas of Tanzania. African Journal of Ecology, 45, 202-15.

Stoner, C, Caro, T, Mduma, SAR, Mlingwa, C, Sabuni, G \& Borner, M (2007) Assessment of effectiveness of protection strategies in Tanzania based on a decade of survey data for large herbivores. Conservation Biology, 21, 635-46.

Southgate, C \& Hulme, D (2000) Uncommon property: The scramble for wetland in southern Kenya. In: Woodhouse, P, Bernstein, H \& Hulme D (Eds.). African enclosures? The social dynamics of wetlands in drylands, pp. 73-117. Oxford, UK: James Currey.

Stewart, DRM \& Zaphiro, DRP (1963) Biomass and density of wild herbivores in different East African habitats. Mammalia, 27, 48396.

Thompson, M \& Homewood, K (2002) Entrepreneurs, elites, and exclusion in Maasailand: trends in wildlife conservation and pastoralist development. Human Ecology, 30, 107-38. 
Van Vliet, N, Nasi, R, Emmons, L, Feer, F, Mbazza, P \& Bourgarel, M (2007) Evidence for the local depletion of bay duiker Cephalophus dorsalis, within the Ipassa Man and Bioshphere Reserve, north-east Gabon. African Journal of Ecology, 45, 440-43.

Walker, BH, Emslie, RH, Owen-Smith, RN \& Scholes, RJ (1987) To cull or not to cull: lessons from a southern African drought. Journal of Applied Ecology, 87, 381-401.

Wato, YA, Wahungu, GM \& Okello, MM (2006). Correlates of wildlife snaring patterns in Tsavo West National Park, Kenya. Biological Conservation, 132, 500-5009.

Webster, PJ, Moore, AM, Loschnigg, JP \& Leben, RR (1999) Coupled ocean-atmosphere dynamics in the Indian Ocean during 1997-1998. Nature, 401, 356-60.

Western D (1973). The structure, dynamics and changes of the Amboseli ecosystem, p. 345, PhD dissertation, University of Nairobi, Nairobi, Kenya.

Western, D (1975) Water availability and its influence on the structure and dynamics of a savannah large mammal community. African Journal of Ecology, 13, 265-86.

Western, D \& Dunne, T (1979) Environmental aspects of settlement site decisions among pastoral Maasai. Human Ecology, 7, 75-98.

Western, D (1982) Amboseli National Park: Enlisting landowners to conserve migratory wildlife. Ambio, 11, 302-8.

Western, D (1994) Ecosystem conservation and rural development: the case of Amboseli. In: Western, D \& Wright, R.M. (Eds.), Natural connections: perspectives in community-based conservation. Island Press, Washington DC, pp. 15-52.

Western, D (2000). Conservation in a human-dominated world. Issues in Science and Technology, 16, 54-60.

Western, D \& Nightingale, DLM (2003) Environmental change on the vulnerability of pastoralists to drought: the Maasai in Amboseli,
Kenya. In: Africa Environmental Outlook: Human Vulnerability to

Environmental Change. Earthprint on behalf of the United Nations Environmental Program. London. Available at:

http://oceandocs.net/bitstream/1834/436/1/Amboseli_maasai.pdf

Western, D \& Maitumo, D (2004) Woodland loss and restoration in a savanna park: a 20-year experiment. African Journal of Ecology, 42, 111-21

Western, D (2007) A half a century of habitat change in Amboseli National Park, Kenya. African Journal of Ecology, 45, 302-10.

Western, D, Russell, S \& Cuthill, I (2009) The status of wildlife in protected areas compared to non-protected areas of Kenya. PLoS One, 4, e6140. Online doi: 10.1371./journal.pone.0006140

Western, D, Groom, R \& Worden, J (2009) The impact of subdivision and sedentarization of pastoral lands on wildlife in an African savanna ecosystem. Biological Conservation, 142, 2538-46.

Western, D (2010) The worst drought: tipping or turning point? Swara, 3, 18-22.

Williams, SD (1998) Grevy's zebra: ecology in a heterogeneous environment, $\mathrm{PhD}$ thesis, University of London.

Wishitemi, B \& Okello, MM (2003) Application of the protected landscape model in southern Kenya. Parks, 13, 12-21.

Worden J, Reid R \& Gichohi H (2003) Land-use impacts on large wildlife and livestock in the swamps of the Greater Amboseli ecosystem, Kajiado District, Kenya, Part 1, Text and Tables. LUCID Working Paper, Series \# 27.

Worden, J, Mose, V \& Western D (2010a) Aerial census of wildlife and livestock in eastern Kajiado in February 2010. African Conservation Center, Nairobi, Kenya 2010.

Worden, J, Mose, V, Western, D (2010b) Aerial census of wildlife and livestock in eastern Kajiado in October 2010. Unpublished Report, African Conservation Centre, Nairobi.

\section{Received: December 07, 2014 \\ (c) Ogutu et al.; Licensee Bentham Open.}

Revised: April 08, 2014

Accepted: April 10, 2014

This is an open access article licensed under the terms of the Creative Commons Attribution Non-Commercial License (http://creativecommons.org/ licenses/by-nc/3.0/), which permits unrestricted, non-commercial use, distribution and reproduction in any medium, provided the work is properly cited. 